Article

\title{
Phenotypic Traits Extraction and Genetic Characteristics Assessment of Eucalyptus Trials Based on UAV-Borne LiDAR and RGB Images
}

\author{
Lihua Liao $^{1}$, Lin Cao ${ }^{1, * \mathbb{D}}$, Yaojian Xie ${ }^{2}$, Jianzhong Luo ${ }^{2}$ and Guibin Wang ${ }^{1}$ \\ 1 Co-Innovation Center for the Sustainable Forestry in Southern China, Nanjing Forestry University, \\ Nanjing 210037, China; liaolh@njfu.edu.cn (L.L.); gbwang@njfu.com.cn (G.W.) \\ 2 China Eucalypt Research Centre, Zhanjiang 524022, China; cercxieyj@163.com (Y.X.); \\ luojz69@hotmail.com (J.L.) \\ * Correspondence: lincao@njfu.edu.cn
}

check for updates

Citation: Liao, L.; Cao, L.; Xie, Y.; Luo, J.; Wang, G. Phenotypic Traits Extraction and Genetic Characteristics Assessment of Eucalyptus Trials Based on UAV-Borne LiDAR and RGB Images. Remote Sens. 2022, 14, 765. https:// doi.org/10.3390/rs14030765

Academic Editor: Shawn C. Kefauver

Received: 15 December 2021

Accepted: 1 February 2022

Published: 7 February 2022

Publisher's Note: MDPI stays neutral with regard to jurisdictional claims in published maps and institutional affiliations.

Copyright: (C) 2022 by the authors. Licensee MDPI, Basel, Switzerland. This article is an open access article distributed under the terms and conditions of the Creative Commons Attribution (CC BY) license (https:// creativecommons.org/licenses/by/ $4.0 /)$.

\begin{abstract}
Phenotype describes the physical, physiological and biochemical characteristics of organisms that are determined or influenced by genes and environment. Accurate extraction of phenotypic data is a prerequisite for comprehensive forest phenotyping in order to improve the growth and development of forest plantations. Combined with the assessments of genetic characteristics, forest phenotyping will help to accelerate the breeding process, improve stress resistance and enhance the quality of the planted forest. In this study, we disposed our study in Eucalyptus trials within the Gaofeng forest farm (a typical Eucalyptus plantation site in southern China) for a high-throughput phenotypic traits extraction and genetic characteristics analysis based on high-density point clouds (acquired by a UAV-borne LiDAR sensor) and high-resolution RGB images (acquired by a UAV-borne camera), aiming at developing a high-resolution and high-throughput UAV-based phenotyping approach for tree breeding. First, we compared the effect of CHM-based Marker-Controlled Watershed Segmentation (MWS) and Point Cloud-based Cluster Segmentation (PCS) for extracting individual trees; Then, the phenotypic traits (i.e., tree height, diameter at breast height, crown width), the structural metrics $(n=19)$ and spectral indices $(n=9)$ of individual trees were extracted and assessed; Finally, a genetic characteristics analysis was carried out based on the above results, and we compared the differences between high-throughput phenotyping by UAV-based data and on manual measurements. Results showed that: in the relatively low stem density site of the trial (760 n/ha), the overall accuracy of MWS and PCS was similar, while in the higher stem density sites (982 n/ha, $1239 \mathrm{n} / \mathrm{ha})$, the overall accuracy of MWS $\left(F_{(2)}=0.93, F_{(3)}=0.86\right)$ was higher than PCS $\left(F_{(2)}=0.84\right.$, $\left.F_{(3)}=0.74\right)$; With the increase of stem density, the difference between the overall accuracy of MWS and PCS gradually expanded. Both UAV-LiDAR extracted phenotypic traits and manual measurements were significantly different across the Eucalyptus clones $(\mathrm{P}<0.05)$, as were most of the structural metrics (47/57) and spectral indices (26/27), revealing the genetic divergence between the clones. The rank of clones demonstrated that the pure clones (of E. urophylla), the hybrid clones (of E. urophylla as the female parent) and the hybrid clones (of E. wetarensis and E. grandis) have a higher fineness of growth. This study proved that UAV-based fine-resolution remote sensing could be an efficient, accurate and precise technology in phenotyping (used in genetic analysis) for tree breeding.
\end{abstract}

Keywords: UAV; LiDAR; phenotyping; Eucalyptus; tree breeding; genetic characteristics analysis; precision silviculture

\section{Introduction}

Phenotype refers to the physical, physiological and biochemical characteristics such as morphology, structure, function of organisms under the combined action of genes and the environment [1,2]. Forest tree phenotype describes the comprehensive expression of height, yield, color, wood properties, stress resistance and other traits in the process of 
forest growth and development, it is the systematic measurement and characterization of different scales of forest (e.g., cells, organs, individuals, populations, forests, etc.) [3-7]. The analysis of phenotypes among forest trees can help accurately estimate the genetic characteristics, thereby improving our understanding of the adaptability of trees and their response to environmental changes, revealing the interaction between tree genes and the environment, as well as effectively correlating genotypes and phenotypes in forest trees for screening the target genes [8]. Although the genetic improvement of some conventional tree species has shown progress, there remains an imbalance between the breeding efficiency and the demands from commercial markets and ecological construction [9]. The development of precision silviculture and forest phenotyping requires the extraction and analysis of high-throughput, non-destructive and accurate data of forest phenotypic traits in order to quantify the genetic principles of specific phenotypes, accelerate forest tree breeding, improve the stress resistance of trees and systematically assess the internal relationship of "genotype-phenotype-environment" [10,11]. Eucalyptus are of great value for their contributions to industrial timber and pulpwood services in countries (e.g., Austria and China etc.) of the world due to its fast growth rate, barren-tolerance, wide adaptability and strong resistance. In Guangxi province, one of the key Eucalyptus plantation and industry provinces of China, the total planation area of Eucalyptus has exceeded 2 million ha, and the annual timber output has exceeded 21 million $\mathrm{m}^{3}$, accounting for approximately $1 / 4$ of the national timber output. Therefore, Eucalyptus plays an important role in ensuring the national timber reserve and supply [12,13]. Although the improved breeding system has been developed in Guangxi province in recent years, the development of Eucalyptus planation remains restricted by challenges such as the degradation of Eucalyptus varieties, reduction of forest quality, and deceleration of yield growth etc. [14,15]. The recent advanced technology of high-throughput phenotypic trait extraction and statistical analysis of the genetic characteristics in forest trees is imperative for supporting genetic breeding of the precision silviculture.

At present, the accurate, precise and high-throughput acquisition of phenotypic traits as well as the development of the approaches for forest phenotyping is of great importance for genetic and tree breeding studies (and applications) [16,17]. The traditional forest phenotype acquisition commonly depends on manual measurements which is time-consuming and labor-intensive, and usually of a small scale with low efficiency, rendering it difficult to meet the needs of modern forest tree breeding. Advanced remote sensing technology, especially the rapidly developed UAV remote sensing system, provides an effective tool capable of obtaining real-time high-dimensional and -throughput phenotypic data with high-accuracy and high-spatial resolution. The phenotypic traits of forest trees can be estimated by combination with novel sensors, sophisticated image processing algorithms and advanced prediction models (e.g., artificial intelligence) [18-20]. UAV-borne LiDAR calculates the distance between the LiDAR sensor and the targets by recording the time interval to obtain high-density and high-precision three-dimensional point cloud data of the ground and forest canopy, which the can be used to visualize the 2D profile characteristics or 3D structural attributes of forest canopies [21]. The phenotypic traits such as tree height, crown width, DBH, volume, biomass, leaf area index can be directly extracted or indirectly obtained (e.g., predicted by inversion models), helping to provide insights into the structural changes and their response to changing environments in tree growth and development [22-26]. The UAV-borne RGB camera, as a convenient, economic and efficient tool for detecting tree crown and spectral reflectance in true color [27,28], can collect high-resolution images and detect the light reflectance variations to obtain the spectral characteristics of forest canopy $[29,30]$. Moreover, it has the potential to quantify the response of forest physiological and biochemical characteristics (e.g., leaf photosynthetic characteristics to environmental factors etc.) so as to effectively characterize the physiological and biochemical characteristics related to phenotypic traits of forest trees [31-33]. However, to the best of our knowledge, there are few studies that have assessed the capability of Eucalyptus phenotypic trait extraction for breeding, based on the advanced multi-source UAV data. 
The extraction of forest phenotypic traits at an individual tree scale shows promise for genetic characteristic analysis of Eucalyptus trials and the selection of superior varieties. There are currently two main approaches for detecting individual trees by using LiDAR point clouds: approaches based on CHM (canopy height model) generated from LiDAR point cloud (e.g., Marker-controlled Watershed Segmentation (MWS) etc.) [34,35] and the approaches based on LiDAR point clouds directly (Point Cloud-based Cluster Segmentation (PCS), etc.) [36,37]. MWS sets a variable window that changes with the tree height and marks the local maximum of CHM as the crown treetop, then uses the watershed algorithm to determine the boundary of individual tree crowns. MWS usually bears strengths in recognizing crown boundaries capable of eliminating "false" crown vertices than ordinary watershed algorithms [38], while PCS judges and clusters a point cloud of individual trees by means of the top-down regional growth segmentation combined with threshold determination to judge the ownership of the target point.

In this study, we disposed a comprehensive UAV-based remote sensing campaign in the Eucalyptus trials of Gaofeng forest farm in Guangxi province of southern China. By using UAV-borne LiDAR data (of high-density point cloud) and RGB images (of highresolution true-color orthophoto) collected by a multi-rotor UAV system, high-throughput phenotypic traits were extracted and analysis of genetic diversion was performed using the calculated results. The specific objectives of this study are: (1) to compare the accuracies of Marker-controlled Watershed Segmentation (MWS) and Point Cloud-based Cluster Segmentation (PCS) for detecting individual trees within the Eucalyptus trials and then extract phenotypic traits (i.e., tree height, diameter at breast height, crown width), the structural metrics $(n=19)$ and spectral indices $(n=9) ;(2)$ to analyze the genetic differences of the phenotypic traits, and the structural and spectral characteristics across the Eucalyptus clones, using the extracted results from the multi-source UAV remote sensing data. UAVLiDAR extracted phenotypic traits and manually measured phenotypic traits were also compared to assess the effectiveness of the UAV technology for phenotypic analysis of forest trees.

\section{Materials and Methods}

In this study, the Canopy Height Model (CHM) was generated based on the LiDAR point cloud obtained from the UAV platform, and the RGB orthophoto was generated based on the high-resolution true-color image. First, the segmentation accuracies of two individual tree segmentation algorithms (MWS and PCS) were evaluated based on the Canopy Height Model (CHM) and the normalized LiDAR point clouds, separately. The structural and spectral characteristics of individual trees in Eucalyptus trials were extracted according to the optimal individual tree segmentation results. Then, a statistical analysis was conducted to assess the genetic differences in phenotypic traits, structural and spectral characteristics. Finally, the genetic parameters were estimated and the superior clones and genetic gain were estimated. The workflow of this study is shown in Figure 1.

\subsection{Study Area}

The study sites are located within the clonal trials of Eucalyptus in the Gaofeng (Stateowned) Forest Farm in Nanning city, Guangxi province $\left(108^{\circ} 14^{\prime} 10^{\prime \prime} \mathrm{E}, 22^{\circ} 56^{\prime} 10^{\prime \prime} \mathrm{N}\right)$ of southern China. The local climate is the southern subtropical monsoon climate with sufficient sunshine and abundant rainfall. The annual average temperature is $21.6{ }^{\circ} \mathrm{C}$, the minimum temperature is $-2{ }^{\circ} \mathrm{C}$, the maximum temperature is $40^{\circ} \mathrm{C}$, and the annual average precipitation ranges from $1200-1500 \mathrm{~mm}$, of which the precipitation from April to September accounts for $79.8 \%$ of the annual precipitation. The annual relative humidity is approximately 79\% [39]. The topography of the study area is a hilly low mountain, with an altitude of approximately 180-250 m and an average slope of approximately $30^{\circ}$. The forest soil is lateritic red soil and the soil thickness is approximately $104-112 \mathrm{~cm}$. The vegetations found below-canopy in the study sites-1 and -2 consists of relatively dense Dicranopteris dichotoma, Evodia lepta, Ficus esquiroliana, Clerodendrum cyrtophyllum, Microlepia hancei, etc. 
The understory vegetation in site-3 consists of relatively sparse Evodia lepta, Clerodendrum cyrtophyllum, Microlepia hancei, etc.

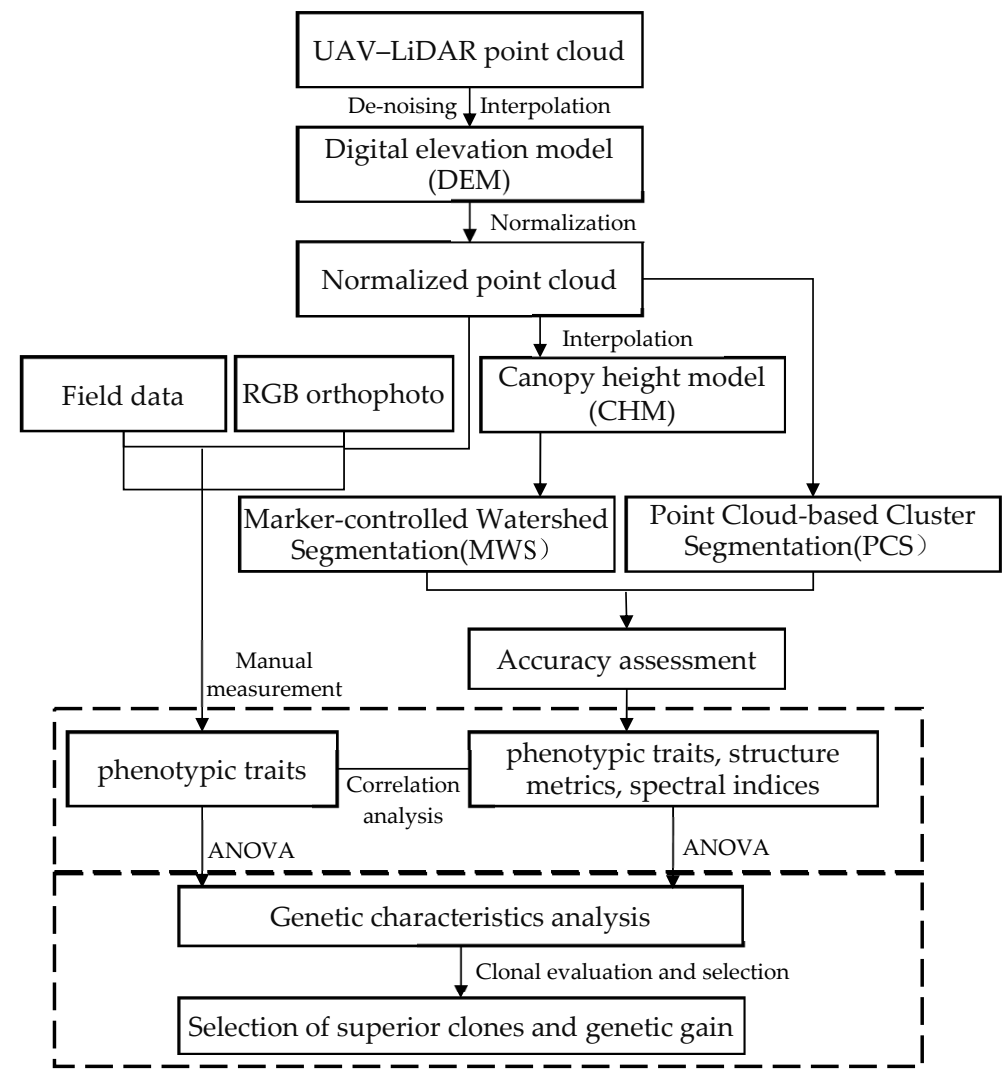

Figure 1. Overview of the workflow in this study.

\subsection{Study Materials}

There are three sites of Eucalyptus trials in the study area. Trees in site- 1 were planted in May 2015, with a total of 16 Eucalyptus clones including 12 Eucalyptus hybrid clones and 4 pure clones. Within site- 1 , there was set up in a randomized complete block design, with 4 rows $\times 5$ plots, 3 replications, 48 plots in total. Trees in site- 2 were planted in June 2016, with a total of 27 Eucalyptus clones including 21 Eucalyptus hybrid clones and 6 pure clones. Within site-2, there was set up in a randomized complete block design, with 4 rows $\times 5$ plots. We measured trees in one of the replications. Eucalyptus in site-3 were planted in June 2018, with a total of 11 Eucalyptus pure clones. Within site-3, there was set up in a randomized complete block design, with 4 rows $\times 5$ plots, 3 or 4 replications, 53 plots in total. See Table A1 for Eucalyptus species information. The locations, Digital Elevation Models (DEMs) and Canopy Height Models (CHMs) are shown in Figures 2 and 3.

\subsection{Field Data and Manual Measurements}

The ground survey was conducted in January 2020. The field measurements of a typical individual tree in each plot include diameter at breast height $(\mathrm{DBH}$, measured with a diameter at a height of $1.3 \mathrm{~m}$ using a breast diameter ruler), tree height $(\mathrm{H}$, using a Vertex ultrasonic altimeter), under-branch height, crown width ( $C$, measured the width of north-south and east-west tree crowns with tape, and calculated the average value)) and positions (Trimble R6 GNSS (Trimble, Sunnyvale, CA, USA)). There were 40, 26, and 48 individual trees measured in site-1, 2, and 3, respectively. 

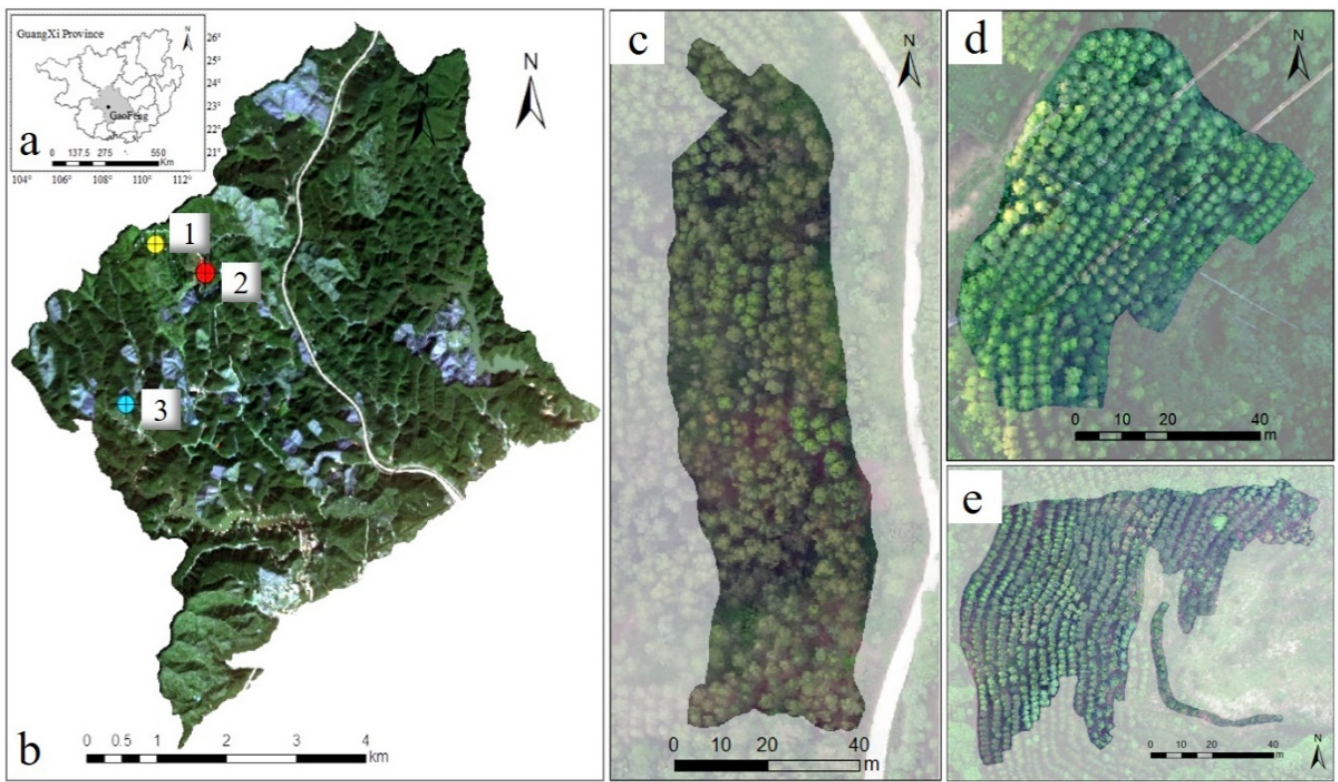

Figure 2. The orthophotos of the study sites of Eucalyptus clone trials (with the spatial distributions and of sites). (a) Location of Gaofeng Forest Farm; (b) Orthophoto of Gaofeng Forest Farm and the spatial distributions of three sites; (c-e) Orthophotos of site-1, 2, 3, respectively.
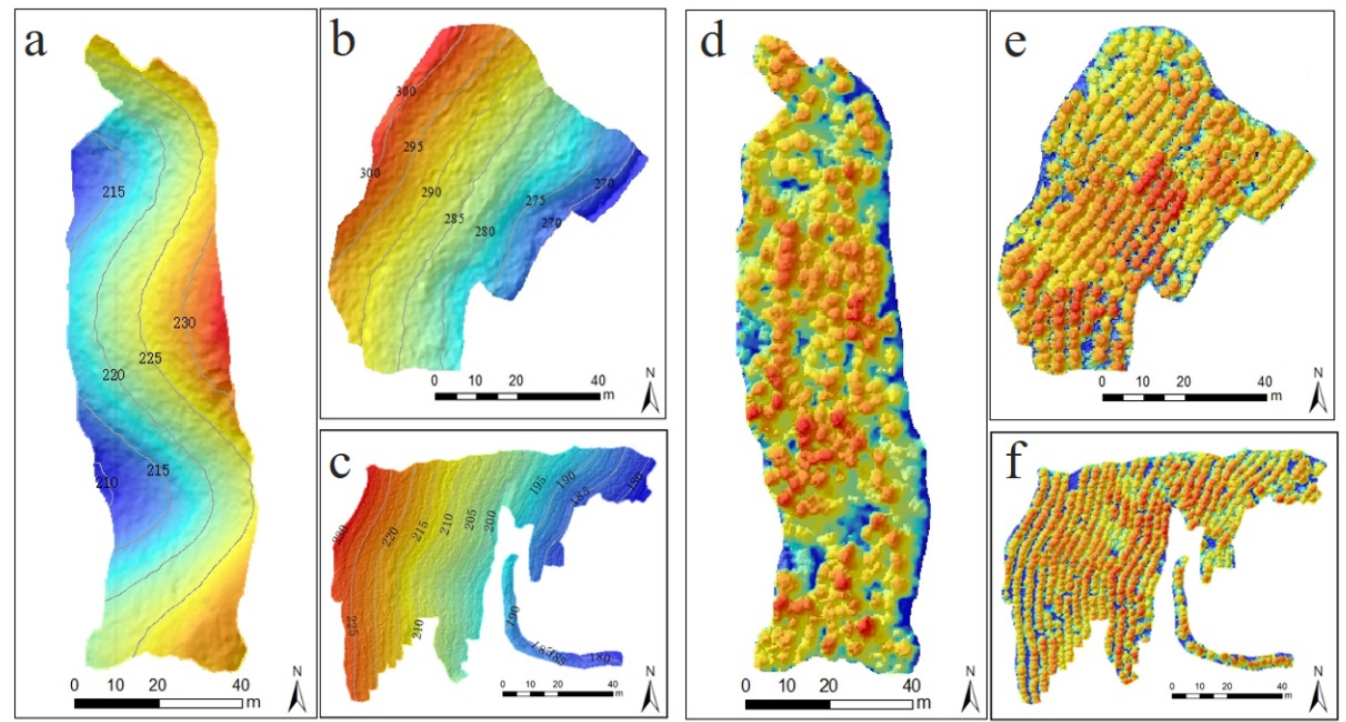

Figure 3. The LiDAR-derived Digital Elevation Models (DEMs) and Canopy Height Models (CHMs) of study areas. (a-c) DEMs of site-1, 2, 3, respectively; (d-f) CHMs of site-1, 2, 3, respectively.

In this study, the individual tree height and crown width derived from manually visual interpretation based on LiDAR high-density point cloud and high-resolution orthophoto combined with field data were regarded as manual measurements (LiDAR manually measured tree height (H1) and orthophoto interpreted crown width (C1) separately). First, the high-resolution orthophoto was registered to the CHM derived from LiDAR highdensity point cloud, and the nearest neighbor pixel method was employed for resampling to obtain spatially matched CHM and RGB orthophoto. Then, we screened and located crowns of individual trees by means of zooming in to the orthophoto and CHM (normalized point clouds were also used as reference data), and drew circles with an average value of the lengths in 2 directions (i.e., the north-south and east-west directions) of each tree as the diameter to represent the crown. Finally, the diameters of each circle were calculated as the orthophoto interpreted crown width (C1), and the value of the highest point in $\mathrm{CHM}$ 
within each circular crown outline were extracted as the LiDAR manually measured tree height $(\mathrm{H} 1)$.

To obtain the $\mathrm{DBH}$ of all individual trees, we established the $\mathrm{DBH}-\mathrm{H}$ regression models by linear function, quadratic function, power function and exponential function using all field tree heights and DBH of individual trees from three sites. The optimal DBH$\mathrm{H}$ model was selected to estimate individual tree DBH. The coefficient of determination $\left(R^{2}\right)$, root mean square error (RMSE) and relative root mean square error ( $\left.r R M S E\right)$ were used to evaluate the DBH-H regression model as the following formula. The 10-fold cross-validation was performed to verify the accuracy of the $\mathrm{DBH}-\mathrm{H}$ regression model. The original sample was randomly partitioned into 10 subsamples. Of the 10 subsamples, a single subsample was retained as the validation data for testing the model, and the remaining 9 subsamples were used as training data, then the average accuracy for 10 iterations was recorded as the final measurement [40].

$$
\begin{gathered}
R^{2}=1-\frac{\sum_{i=1}^{n}\left(x_{i}-\hat{x}_{i}\right)^{2}}{\sum_{i=1}^{n}\left(x_{i}-\bar{x}_{i}\right)^{2}} \\
\text { RMSE }=\sqrt{\frac{1}{\frac{1}{n} \sum_{i=1}^{n}\left(x_{i}-\hat{x}_{i}\right)^{2}}} \\
\text { rRMSE }=\frac{R M S E}{\bar{x}_{i}} \times 100 \%
\end{gathered}
$$

where $x_{i}$ is value of a phenotypic trait, $\bar{x}_{i}$ is average value of a phenotypic trait; $\hat{x}_{i}$ is the model estimated value of a phenotypic trait, $\mathrm{n}$ is the number of trees. The LiDAR manually estimated DBH (DBH1) was calculated based on the optimal DBH-H model and H1.

\subsection{UAV-Borne LiDAR Data Acquisition and Preprocessing}

The LiDAR data were obtained by RIEGL VUX-1LR carried by a multi-rotor UAV platform during 26-27 May 2020. The parameters of the UAV-borne LiDAR are as follows: flight altitude $250 \mathrm{~m}$, flight speed $7 \mathrm{~m} / \mathrm{s}$, strip width $598.9 \mathrm{~m}$, flight-direction overlap rate and side overlap rate $90 \%$, scanning frequency $200 \mathrm{KHz}$, pulse emission frequency $820 \mathrm{KHz}$, divergence $0.5 \mathrm{mrad}$, laser footprint diameter $0.06 \mathrm{~m}$, measurement accuracy $15 \mathrm{~mm}$ and an average point density of approximately $264.5 \mathrm{pts} / \mathrm{m}^{-2}$.

LiDAR data preprocessing was as follows: First, we set a height threshold to remove noise in the original LiDAR data. Then, we classified and extracted ground points using an improved progressive encryption triangulated irregular network (TIN) densification filtering algorithm (IPTD) [41]. Next, we generated the Digital Elevation Model (DEM, $0.3 \mathrm{~m}$ ) by inverse distance weighted interpolation (IDW). Finally, the Canopy Height Model (CHM, $0.3 \mathrm{~m}$ ) from LiDAR point clouds was generated according to the DEM. The LiDAR metrics extracted from the normalized LiDAR point cloud include: distributional metrics $(n=13)$, Weibull-fitting metrics $(n=2)$, and canopy volume metrics $(n=4)$ (Table 1) 
Table 1. Description of the LiDAR metrics with equations and references separately.

\begin{tabular}{|c|c|c|}
\hline Metrics & Description & Reference \\
\hline \multicolumn{3}{|c|}{ Distributional metrics } \\
\hline $\mathrm{h}_{25}, \mathrm{~h}_{50}, \mathrm{~h}_{75}, \mathrm{~h}_{95}$ & $\begin{array}{l}\text { The percentiles of the canopy height distributions by first echo } \\
\text { (25th, 50th, 75th and 95th). }\end{array}$ & {$[42]$} \\
\hline $\mathrm{H}_{\text {mean }}$ & The mean height of all points after normalized. & {$[42]$} \\
\hline $\mathrm{H}_{c v}$ & $\begin{array}{l}\text { The coefficient of variation of height of all points after normalized } \\
\text { (the ratio of the standard deviation to the mean)) }\end{array}$ & {$[42]$} \\
\hline $\mathrm{d}_{1}, \mathrm{~d}_{3}, \mathrm{~d}_{5}, \mathrm{~d}_{7}, \mathrm{~d}_{9}$ & $\begin{array}{l}\text { The proportion of points above the quantiles (10th, 30th, } \\
50 \text { th,70th, and 90th) to total number of points }\end{array}$ & [43] \\
\hline $\mathrm{CC}_{2 \mathrm{~m}}$ & $\begin{array}{l}\text { The first return points above } 2 \mathrm{~m} \text { accounts for the percentage of } \\
\text { all return points }\end{array}$ & {$[42]$} \\
\hline eLAI & Half of the total leaf area per unit ground area & [44] \\
\hline \multicolumn{3}{|c|}{ Weibull-fitting metrics } \\
\hline$\alpha / \beta$ & $\begin{array}{l}\text { The } \alpha \text { and } \beta \\
\text { parameter of the Weibull distribution fitted to foliage } \\
\text { density profile. }\end{array}$ & [45] \\
\hline \multicolumn{3}{|c|}{ Canopy volume metrics } \\
\hline $\begin{array}{l}\text { Open gap zone }(\mathrm{OP}) / \\
\text { Closed gap zone }(\mathrm{CL})\end{array}$ & $\begin{array}{l}\text { The empty voxels located above and below the canopy } \\
\text { respectively. }\end{array}$ & [46] \\
\hline $\begin{array}{l}\text { Euphotic zone (EU)/ } \\
\text { Oligophotic zone (OL) }\end{array}$ & $\begin{array}{l}\text { The voxels located within an uppermost percentile }(65 \%) \text { of all } \\
\text { filled grid cells of that column, and voxels located below the point } \\
\text { in the profile }\end{array}$ & [46] \\
\hline
\end{tabular}

\subsection{UAV-Borne RGB Orthophoto Acquisition and Preprocessing}

The RGB images were obtained by FC6310R carried by DJI-PHANTOM 4-RTK during 26-27 May 2020. The parameters were as follows: flight altitude $250 \mathrm{~m}$, flight speed $10 \mathrm{~m} / \mathrm{s}$, flight-direction overlap rate and side overlap rate are about $80 \%$, focal length $9 \mathrm{~mm}$, exposure time $1 / 320 \mathrm{~s}$, ISO 200, aperture value $\mathrm{f} / 5.6$, ground sampling distance (GSD) $6.85 \mathrm{~cm}$.

The preprocessing of RGB images included the following: First, alignment of images with the help of five parameters (latitude, longitude, elevation, roll, pitch and heading) of each image recorded in real time by in-flight internal GPS data and inertial measurement units (IMUs). Then, the aligned images could be spliced and resampled together to generate a high-resolution true-color orthophoto $(0.1 \mathrm{~m})$ using Structure-from-Motion (SfM) image reconstruction. Finally, extraction of the pixel values of different bands at an individual tree scale based on the optimal individual tree segmentation. The vegetation indices calculated are shown in Table 2.

Table 2. Description of visible vegetation indices (VI) with equations and references separately.

\begin{tabular}{ccc}
\hline Vegetation Index & Equation & Reference \\
\hline Brightness $(\mathrm{BI})$ & $\mathrm{G}+\mathrm{R}+\mathrm{B}$ & {$[47]$} \\
NormG $(\mathrm{NG})$ & $\mathrm{G} /(\mathrm{G}+\mathrm{R}+\mathrm{B})$ & {$[47]$} \\
RGRI & $\mathrm{R} / \mathrm{G}$ & {$[48]$} \\
GRVI & $(\mathrm{G}-\mathrm{R}) /(\mathrm{G}+\mathrm{R})$ & {$[59]$} \\
VARI & $(\mathrm{G}-\mathrm{R})(\mathrm{G}+\mathrm{R}-\mathrm{B})$ & {$[51]$} \\
VDVI & $(2 \mathrm{G}-(\mathrm{R}+\mathrm{B})) /(2 \mathrm{G}+(\mathrm{R}+\mathrm{B}))$ & {$[52]$} \\
EXG & $(2 \mathrm{G}-\mathrm{R}-\mathrm{B}) /(\mathrm{R}+\mathrm{G}+\mathrm{B})$ & {$[52]$} \\
EXG-R & $((3 \mathrm{G}-2.4 \mathrm{R}-\mathrm{B}) /(\mathrm{R}+\mathrm{G}+\mathrm{B})$ & {$[53]$} \\
CIVE & $((0.411 \mathrm{R}-0.811 \mathrm{G}+0.385 \mathrm{~B}) /(\mathrm{R}+\mathrm{G}+\mathrm{B}))+18.787$ &
\end{tabular}

Note: The vegetation indices were calculated using raw imagery bands; R, Red band; G, Green band; B, Blue band. 


\subsection{Individual Tree Segmentation Methods}

Method 1: Marker-controlled Watershed Segmentation (MWS), First, the method generated the Canopy Maxima Model (CMM) by filtering CHM with variable window sizes determined by the lower-limit of the prediction intervals of the regression curve between crown size and tree height. Then, the treetops were detected and marked by searching local maxima in a smoothed CMM with variable window sizes. Next, the initial delineation of tree crowns was segmented using marker-controlled watershed segmentation, it is assumed that water is injected from each marked treetop, and the water is gradually immersed to form multiple "ponding basins", the region of each marked treetop is surrounded by the corresponding "dam" as the initial delineation of tree crowns after segmentation. Lastly, the final tree crowns are obtained by distance transformation $[54,55]$.

Method 2: Point Cloud-based Cluster Segmentation (PCS). The principle of PCS is top-down regional growth combined with threshold determination based on normalized point clouds directly. This approach sets the horizontal distance as the threshold between tree vertices according to the phenomenon of certain distance between trees. First, to assume that the highest point in the normalized LiDAR point cloud is the tree vertex, and judge distance iteratively from tree vertex to bottom: If the horizontal distance between the target point and the vertex of individual tree is greater than the threshold, the target point belongs to another individual tree point cloud cluster; If not, the ownership of the target point is determined through additional filter rules. Finally, the steps are repeated until the bottom points are segmented $[34,37]$. The accuracy evaluation indexes of individual tree segmentation were as follows $[56,57]$.

$$
\begin{gathered}
r=\frac{N_{t}}{N_{t}+N_{o}} \\
p=\frac{N_{t}}{N_{t}+N_{c}} \\
F=\frac{2(r \times p)}{r+p}
\end{gathered}
$$

where $r$ represents the tree detection rate, $p$ represents the tree detection accuracy, and $F$ represents the overall accuracy taking both omission and commission into consideration. $N_{t}$ is the number of trees detected by the algorithm and corresponds to the measured trees in the field. $N_{O}$ is the number of trees that cannot be detected by the algorithm but exist in the field. $N_{C}$ is the number of trees detected by the algorithm but do not exist in the field.

\subsection{Statistical Analysis Methods}

In this study, the phenotypic traits (tree height, crown width) of individual trees were extracted using the optimal individual tree segmentation result as the LiDAR extracted tree height (H2) and LiDAR extracted crown width (C2). The LiDAR estimated DBH (DBH2) was derived from the optimal DBH-H model and $\mathrm{H} 2$. Based on the above results. Scatter plots were used to compare the UAV-LiDAR extracted phenotypic traits, measured data and manual measurements. The correlations between phenotypic traits and LiDAR metrics and vegetation index were compared by Pearson correlation coefficient.

Statistical analysis was then performed on the phenotypic traits and the structural, spectral characteristics to analyze the differences across the Eucalyptus clones and the relationship between Eucalyptus phenotypic traits and structural, spectral characteristics. Variations among clones within these sites were analyzed by ANOVA using following linear mixed model: $X_{i j k}=\mu+C_{i}+B_{j}+C B_{i j}+\varepsilon_{i j j}$, where $X_{i j k}$ represents the phenotypic value of an individual tree $k$ of clone $i$ in replication $j, \mu$ represents the overall mean, $C_{i}$ represents genetic effect (random) of clone $i, B_{j}$ represents effect (fixed) of replication $j$, and $C B_{i j}$ represents the interaction effect (random) of clone $i$ and replication $j, \varepsilon_{i j k}$ represents random error. The restricted or residual maximum likelihood algorithm (REML) was used to perform variance component estimation for the statistical analysis. The genetic parameters 
of Eucalyptus phenotypic traits and preferred three indexes include phenotypic coefficients of variation $(P C V)$, genotypic coefficients of variance $(G C V)$, repeatability of clones $\left(R_{c}\right)$, and repeatability of individual trees $\left(R_{i}\right)$ [58-60] were estimated by the following formula:

$$
\begin{gathered}
P C V=\frac{\sqrt{\sigma_{c}^{2}+\sigma_{\mathrm{cr}}^{2}+\sigma_{e}^{2}}}{\bar{X}} \times 100 \% \\
G C V=\frac{\sqrt{\sigma_{c}^{2}}}{\bar{X}} \times 100 \% \\
R_{c}=\frac{\sigma_{c}^{2}}{\sigma_{c}^{2}+\sigma_{w}^{2} / r} \\
R_{i}=\frac{\sigma_{c}^{2}}{\sigma_{c}^{2}+\sigma_{w}^{2}}
\end{gathered}
$$

where $\bar{X}$ is the mean value of the trait, $\sigma_{c}^{2}$ is the clonal variance component, $\sigma_{c r}^{2}$ is the interaction of the replication and the clone variance, $\sigma_{e}^{2}$ is the residual variance component, $\sigma_{w}^{2}$ is the environment variance component, $r$ is the number of replications. Repeatability, the ideal heritability in a broad sense for a trait ranged from 0 to 1 , can indicate the stability of gene expression of a trait in a fluctuating environment, the higher the repeatability, the greater the influence of gene on phenotypic traits, and the more reliable the clonal selection [61-64].

An improved method of multi-trait comprehensive evaluation was used to assess the clones according to the phenotypic traits extracted from the remote sensing data and the photogrammetric data use of Eucalyptus as pulpwood. Tree height and DBH were the most important traits in the process of superior material evaluation. The formula used was as follows [65]:

$$
Q_{i}=\sum K_{j}\left(1-\frac{X_{i j}}{X_{0}}\right)
$$

where $Q_{i}$ is the comprehensive evaluation value of each clone ranged between 0 and 1 , the smaller the value of $Q_{i}$, the higher the excellence of the clone, $K_{j}$ is the weight set by the importance of phenotypic traits and the use of Eucalyptus as pulp wood in this study, $K_{j}=(H, D B H, C)=(0.6,0.3,0.1), X_{i j}$ is the average value of one trait, $X_{0}$ is the maximum value of the trait, $\mathrm{n}$ is the number of traits. The $Q_{i 1}$ thereby was calculated based on manual measurements (i.e., $\mathrm{H} 1, \mathrm{DBH} 1$ and $\mathrm{C} 1$ ) and the $Q_{i 2}$ was calculated based on LiDAR extracted phenotypic traits (i.e., H2, DBH2 and C2).

Genetic gain, closely related to the level of repeatability and the degree of trait variation, represents the improvement effect of selection. The genetic gain was estimated using the following formula $[66,67]$ :

$$
\Delta G=\frac{(\bar{x}-\bar{X}) \times R_{c}}{\bar{X}} \times 100
$$

where $R_{c}$ is the repeatability of clone; $\bar{x}$ is mean of selected clones; and $\bar{X}$ is the mean value of all parent. In this study, the mean value of all tested clones was used to represent the mean value of all parents at each site [63].

\section{Results}

\subsection{Individual Tree Segmentation}

The effects of individual tree segmentation are shown in Figure 4. The manually interpreted crown vertices and the crown boundaries were displayed, as well as crown vertices obtained by the two segmentation methods. In the three sites, the average canopy 
widths were $4.16 \mathrm{~m}, 3.38 \mathrm{~m}$, and $3.06 \mathrm{~m}$, respectively, while the stem density were $760 \mathrm{n} / \mathrm{ha}$, $982 \mathrm{n} / \mathrm{ha}, 1239 \mathrm{n} / \mathrm{ha}$, respectively. The canopy boundaries depicted by MWS with better visual effect are closer to the actual canopy boundaries than PCS. In the low density site-1, the overall accuracy $(F)$ of MWS and PCS was similar, whereas the tree detection rate of MWS $\left(r_{(1)}=0.74\right)$ was lower than PCS $\left(r_{(1)}=0.87\right)$, the tree detection accuracy of MWS $\left(p_{(1)}=0.87\right)$ was higher than PCS $\left(p_{(1)}=0.73\right)$. In the higher-density sites-2 and -3 , both MWS and PCS had the higher over-segmentation phenomenon $\left(N_{C}\right)$ than the missing segmentation phenomenon $\left(N_{O}\right)$, while the tree detection rate and tree detection accuracy of MWS $\left(r_{(2)}=0.94, r_{(3)}=0.92, p_{(2)}=0.92, p_{(3)}=0.81\right)$ were higher than PCS $\left(r_{(2)}=0.93\right.$, $\left.r_{(3)}=0.84, p_{(2)}=0.76, p_{(3)}=0.67\right)$. With the increase of forest stem density in three sites, the difference between the overall accuracy of MWS and PCS gradually expanded (Table 3). The segmentation results of MWS were selected for subsequent analysis based on the above'results.
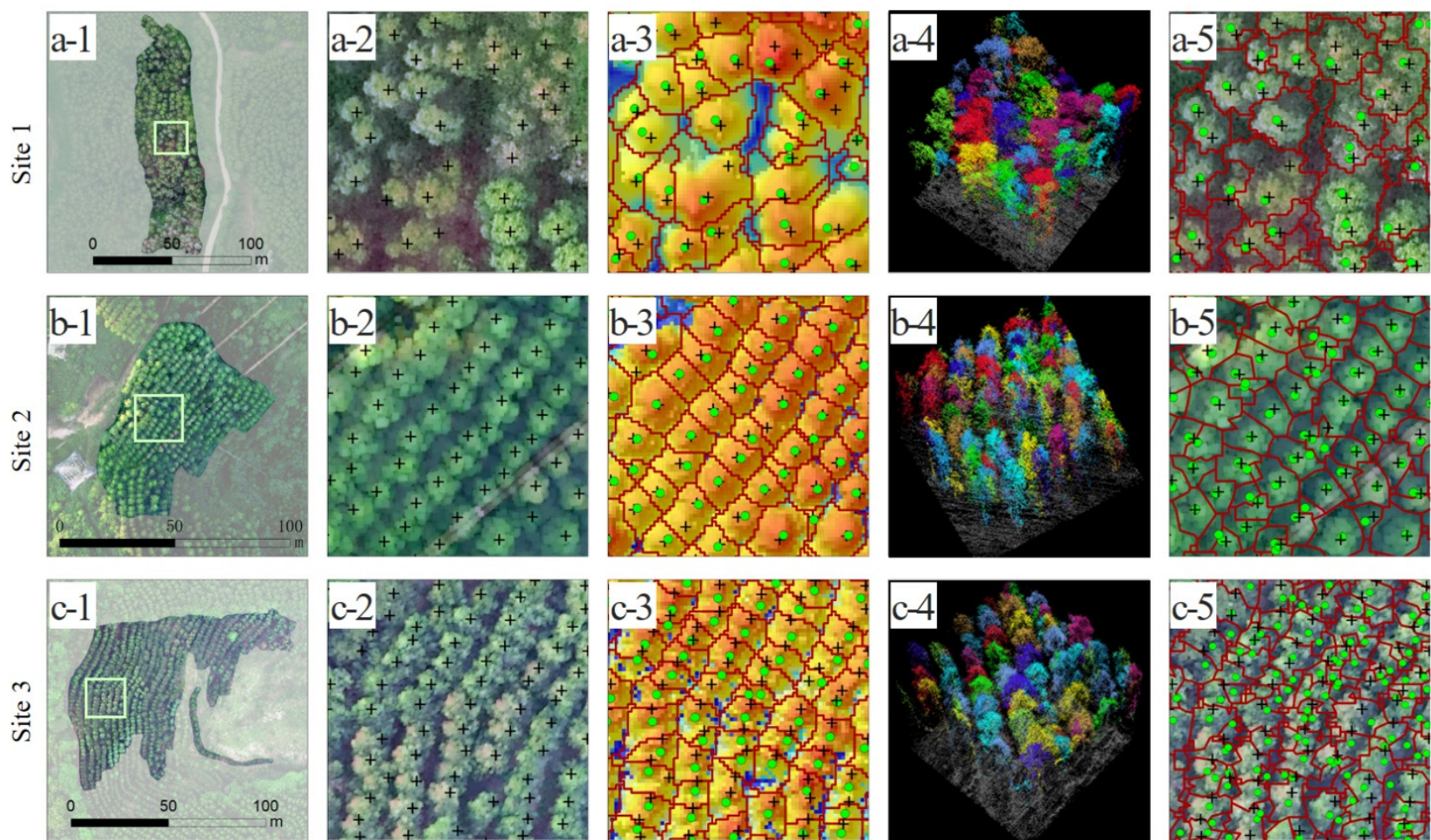

High-resolution true-color orthophoto

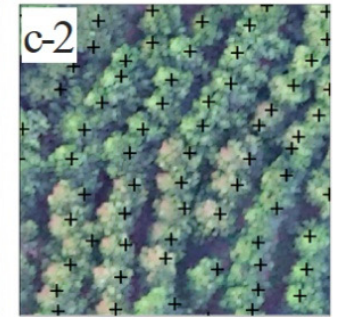

$20 \times 20 \mathrm{~m}$ sample area

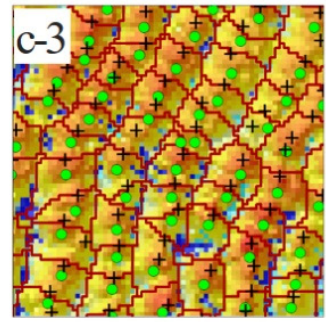

Segmentation boundary of MWS

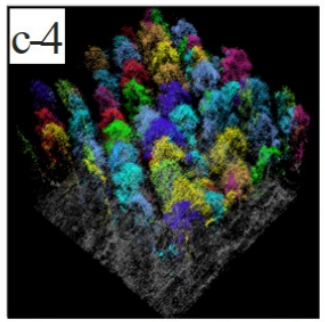

Segmentation effect of PCS

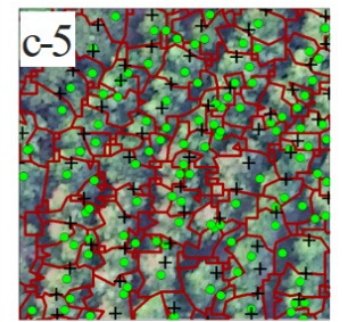

Segmentation boundary of PCS

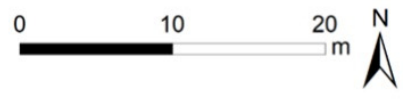

Figure 4. (a1-a5, b1-b5, c1-c5) MWS and PCS individual tree segmentation results in the three sites. MWS, Mark-controlled Watershed Segmentation method; PCS: Point Cloud-based Cluster Segmentation.

Table 3. The accuracy assessments for the individual tree segmentation algorithms of MWS and PCS.

\begin{tabular}{|c|c|c|c|c|c|c|c|c|c|}
\hline Site & $\begin{array}{l}\text { Stem Density } \\
\text { (n/ha) }\end{array}$ & Crown Width (m) & Method & $N_{t}$ & $N_{O}$ & $N_{C}$ & $r$ & $p$ & $F$ \\
\hline \multirow[t]{2}{*}{1} & \multirow[t]{2}{*}{760} & $\begin{array}{c}\max =6.67 \\
\operatorname{mean}=4.18\end{array}$ & MWS & 278 & 98 & 42 & 0.74 & 0.87 & 0.80 \\
\hline & & $\begin{array}{c}\text { mean }=4.18 \\
\min =2.06\end{array}$ & PCS & 327 & 49 & 118 & 0.87 & 0.73 & 0.80 \\
\hline
\end{tabular}


Table 3. Cont.

\begin{tabular}{cccccccccc}
\hline Site & $\begin{array}{c}\text { Stem Density } \\
\text { (n/ha) }\end{array}$ & Crown Width (m) & Method & $N_{t}$ & $N_{\boldsymbol{O}}$ & $N_{C}$ & $\boldsymbol{r}$ & $\boldsymbol{p}$ & $\boldsymbol{F}$ \\
\hline \multirow{2}{*}{2} & 982 & $\max =4.54$ & MWS & 343 & 20 & 31 & 0.94 & 0.92 \\
& & $\begin{array}{c}\text { mean }=3.38 \\
\min =2.14\end{array}$ & PCS & 338 & 25 & 105 & 0.93 & 0.76 & 0.84 \\
\hline \multirow{2}{*}{3} & 1239 & $\max =4.06$ & MWS & 632 & 57 & 145 & 0.92 & 0.81 & 0.86 \\
& & $\begin{array}{c}\text { mean }=3.05 \\
\text { min }=2.18\end{array}$ & PCS & 581 & 108 & 291 & 0.84 & 0.67 & 0.74 \\
\hline
\end{tabular}

Note: MWS: Marker-controlled Watershed Segmentation; PCS: Point Cloud-based Cluster Segmentation; $N_{t}, N_{O}$ $N_{C}, r, p, F$ are described in Equations (4)-(6).

\subsection{Statistical Analysis}

\subsubsection{Diameter at Breast Height (DBH) - Tree Height (H) Regression Model}

The correlation coefficient value ( $\mathrm{r}$ ) calculated between the field measured tree height and the field measured DBH was 0.89 . The results of accuracy assessments and crossvalidation show that the DBH-H regression model established by exponential function fitted best $\left(R^{2}=0.78\right)$ (Table 4$)$. We chose the $\mathrm{DBH}-\mathrm{H}$ regression model established by exponential function to predicted individual tree DBH. The DBH1 was derived from the $\mathrm{DBH}-\mathrm{H}$ regression model and $\mathrm{H} 1$, and the $\mathrm{DBH} 2$ was derived from $\mathrm{DBH}-\mathrm{H}$ regression model and $\mathrm{H} 2$.

Table 4. The results of accuracy assessments and cross-validation of DBH-tree height regression model.

\begin{tabular}{|c|c|c|c|c|c|c|c|}
\hline \multirow{2}{*}{ Functions } & \multirow{2}{*}{ Models } & \multirow{2}{*}{$\mathrm{R}^{2}$} & \multirow{2}{*}{$R M S E / \mathrm{cm}$} & \multirow{2}{*}{$r R M S E / \%$} & \multicolumn{3}{|c|}{ Cross-Validation } \\
\hline & & & & & $\mathbf{R}^{2}$ & RMSE/cm & $r R M S E / \%$ \\
\hline $\begin{array}{l}\text { Linear } \\
\text { function }\end{array}$ & $\mathrm{D}=0.7175 \mathrm{H}+1.5791$ & 0.80 & 1.50 & 13.74 & 0.77 & 1.54 & 14.12 \\
\hline $\begin{array}{l}\text { Quadratic } \\
\text { function }\end{array}$ & $\begin{array}{c}\mathrm{D}=-0.0187 \mathrm{H}^{2}+1.2227 \\
\mathrm{H}-1.5491\end{array}$ & 0.78 & 1.54 & 14.10 & 0.76 & 1.55 & 14.22 \\
\hline $\begin{array}{l}\text { Power } \\
\text { function }\end{array}$ & $\mathrm{D}=1.2152 \mathrm{H}^{0.8547}$ & 0.80 & 1.50 & 13.74 & 0.76 & 1.53 & 14.03 \\
\hline $\begin{array}{l}\text { Exponential } \\
\text { function }\end{array}$ & $\mathrm{D}=4.3920 \mathrm{e}^{0.0668 \mathrm{H}}$ & 0.81 & 1.48 & 13.56 & 0.78 & 1.51 & 13.85 \\
\hline
\end{tabular}

Note: D, predicted DBH (cm); H. Tree height (m).

\subsubsection{Phenotypic Traits and Analysis}

Scatter plots of LiDAR extracted phenotypic traits and field measurements, manual measurements in the three sites showed that the LiDAR extracted tree height $(\mathrm{H} 2)$ was higher than field-measured tree height while the $R^{2}$ is $0.55,0.68,0.53$, respectively. In the comparison between LiDAR extracted phenotype traits and manual measurements, the $\mathrm{H} 2$ were highly correlated with the $\mathrm{H} 1\left(r>0.94, R^{2}>0.91\right)$, as well as the DBH2 and DBH1 $\left(r>0.94, R^{2}>0.91\right)$, but correlations between the $\mathrm{C} 2$ and $\mathrm{C} 1$ were rather low for $\mathrm{r}$ ranging from 0.42 to 0.80 (Figure 5). The results of correlations between different phenotypic traits showed that there was a strong correlation between tree height and $\mathrm{DBH}$, as the $\mathrm{DBH}$ was obtained from the $\mathrm{DBH}-\mathrm{H}$ regression model, while the correlations between crown width and $\mathrm{DBH}$, tree height were low (Table A3). 

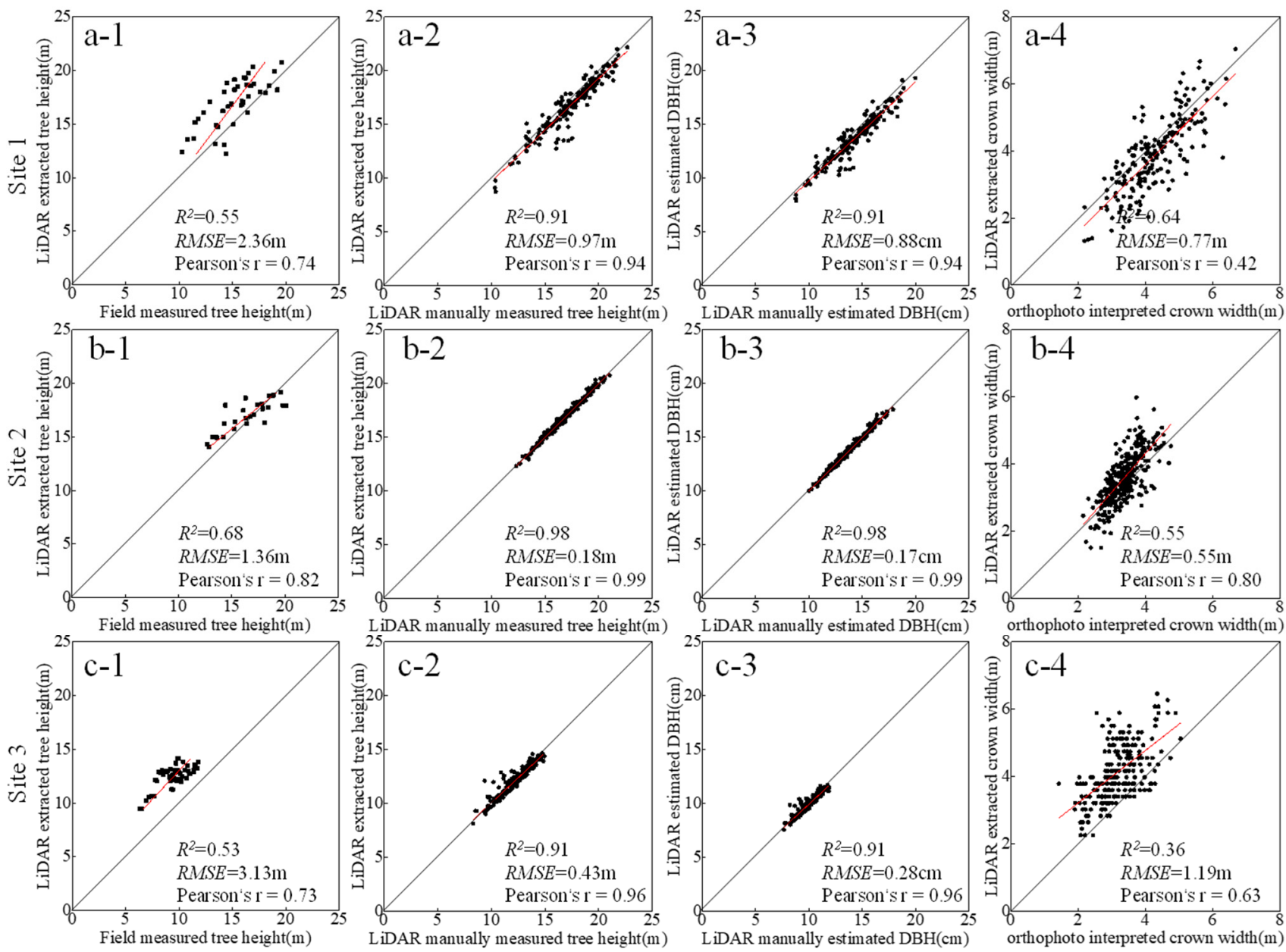

Figure 5. Scatter plots of phenotypic traits extracted from LiDAR point cloud and validation data. (a1-a4) validation results of Eucalyptus phenotypic traits in site-1; (b1-b4) validation results of Eucalyptus phenotypic traits in site-2; (c1-c4) validation results of Eucalyptus phenotypic traits in site-3.

The site- 1 would be selected as the low-density site and the site- 3 would be chosen as the high-density site for the following statistical analysis (assessments of genetic parameters were not conducted in site- 2 as there was no data collected from other replications). The results of ANOVAs showed that there were significant $(\mathrm{P}<0.05)$ differences in phenotypic traits among clones, which indicated there was genetic divergence in phenotypic traits and it was feasible to evaluate and select superior clones (Table 5).

Table 5. F-values and significance levels of ANOVAs from different sources for phenotypic traits of three sites.

\begin{tabular}{ccccccc}
\hline Types of Variation & H1 $\mathbf{( m )}$ & H2 (m) & DBH1 (cm) & DBH2 (cm) & C1 (m) & C2 (m) \\
\hline Low-densitysite & & & & & & \\
Mean \pm std & $17.49 \pm 1.9$ & $17.08 \pm 1.96$ & $14.32 \pm 1.73$ & $13.93 \pm 1.73$ & $4.22 \pm 0.52$ & $4.18 \pm 0.69$ \\
Replication & 0.32 & 0.93 & 0.43 & 1.06 & 2.88 & 0.87 \\
Clone & $2.25^{*}$ & $2.63^{*}$ & $2.16^{*}$ & $2.41^{*}$ & $2.11^{*}$ & $2.22^{*}$ \\
Clone $\times$ replication & 3.71 & 10.12 & 3.21 & 8.82 & 61.76 & 0.38 \\
High-density site & & & & & \\
Mean \pm std & $12.29 \pm 1.00$ & $12.27 \pm 1.05$ & $10.02 \pm 0.66$ & $10.01 \pm 0.69$ & $3.05 \pm 0.39$ & $4.09 \pm 0.46$ \\
Replication & 1.76 & 1.07 & 1.84 & 1.23 & 1.32 & $4.30^{* *}$ \\
\hline
\end{tabular}


Table 5. Cont.

\begin{tabular}{ccccccc}
\hline Types of Variation & H1 $(\mathbf{m})$ & H2 $(\mathbf{m})$ & DBH1 $(\mathbf{c m})$ & DBH2 $(\mathbf{c m})$ & C1 (m) & C2 (m) \\
\hline Clone & $8.59^{* *}$ & $9.68^{* *}$ & $8.42^{* *}$ & $9.22^{* *}$ & $2.84^{*}$ & $3.59^{* *}$ \\
Clone $\times$ replication & 3.02 & 2.04 & 3.55 & 1.98 & 3.42 & 2.90 \\
\hline
\end{tabular}

Note: *: significant difference $(\mathrm{P}<0.05)$; ${ }^{* *}$ : extremely significant difference $(\mathrm{P}<0.01) . \mathrm{H} 1, \mathrm{LiDAR}$ manually measured tree height; H2, LiDAR extracted tree height; DBH1, LiDAR manually estimated DBH; DBH2, LiDAR estimated DBH; C1, orthophoto interpreted crown width; 2 , LiDAR extracted crown width.

\subsubsection{LiDAR Metrics and Vegetation Indices Extraction and Analysis}

Most of the LiDAR Metrics (47/57) and visible vegetation indices $(26 / 27)$ differed significantly among clones in the three sites $(\mathrm{P}<0.01)$ (Table A2). We then screened six indicators with significant differences ( $\left.\mathrm{h}_{95}, \mathrm{E}, \alpha, \mathrm{BI}, \mathrm{VDVI}, \mathrm{EXG}\right)$ to make box plots for showing the differences among different clones (Figures 6 and 7). The correlation analysis results showed that the phenotypic traits had significant but weak correlation with most LiDAR metrics, while the phenotypic traits value had no significant correlation with most vegetation indices (Table A3).
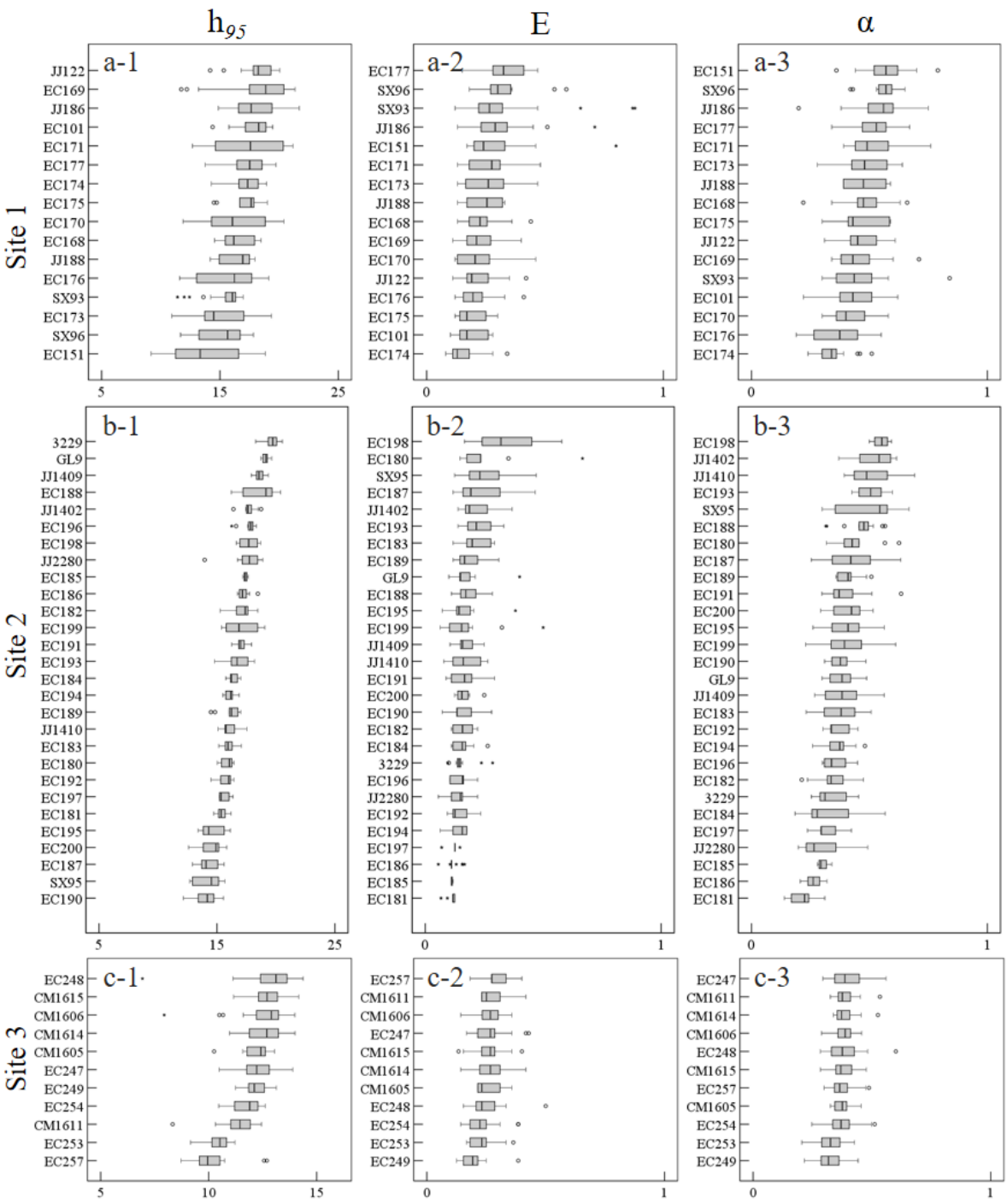

Figure 6. Difference of LiDAR metrics $\left(\mathrm{h}_{95}, \mathrm{E}, \alpha\right)$ among different Eucalyptus clones in three sites. (a1-a3) LiDAR metrics of site-1; (b1-b3) LiDAR metrics of site-2; (c1-c3) LiDAR metrics of site-3. The descriptions of LiDAR metrics are shown in Table 1 , and the descriptions of clones are shown in Table A1. 

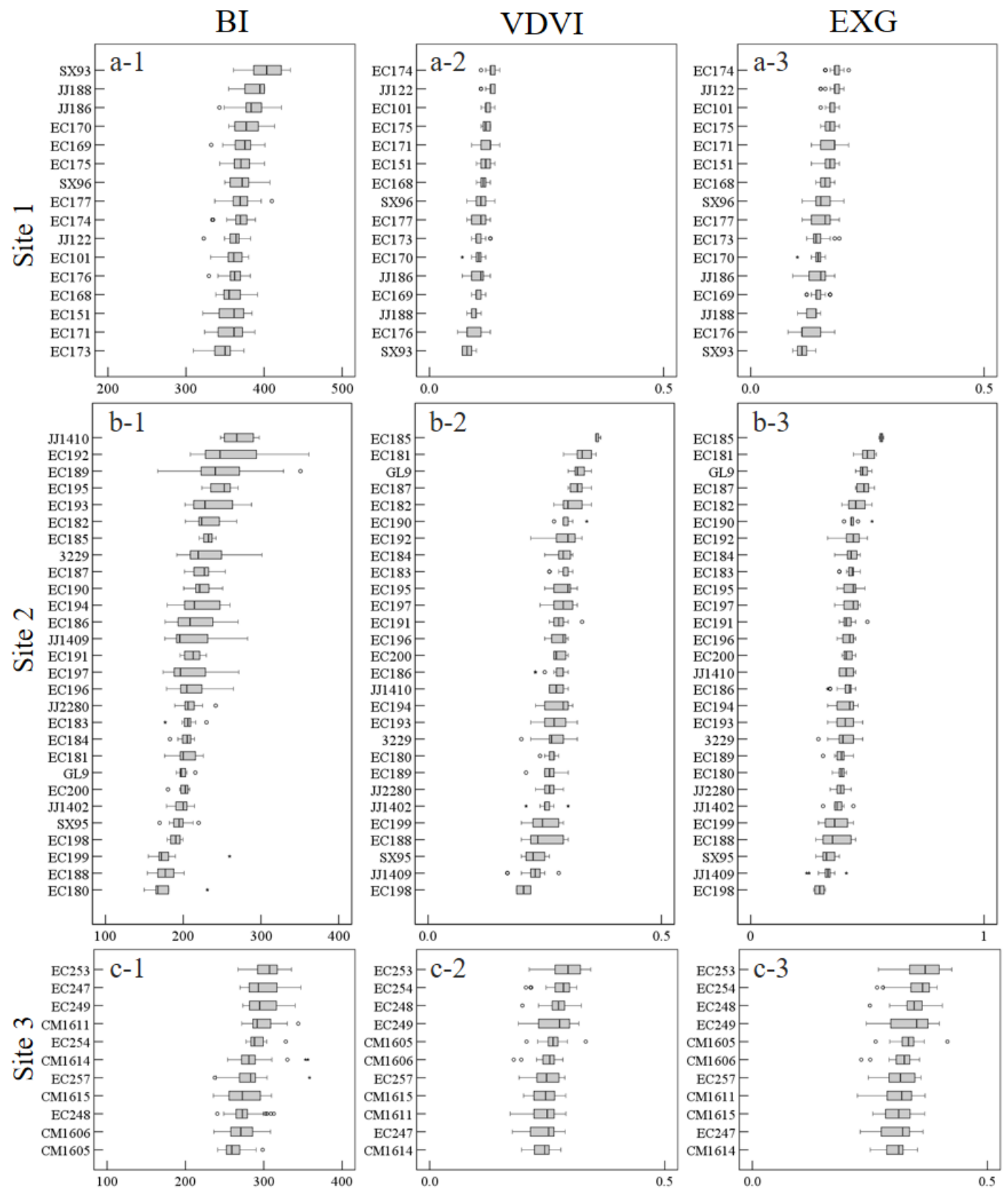

Figure 7. Difference of vegetation indices (BI, VDVI, EXG) among different Eucalyptus clones in three sites (a1-a3) vegetation indices of site-1; (b1-b3) vegetation indices of site-2; (c1-c3) vegetation indices of site-3. The descriptions of vegetation indices are shown in Table 2 , and the descriptions of clones are shown in Table A1.

\subsection{Genetic Parameters and Clone Evaluation}

In the low-density site, the PCV and GCV ranged from 0.062 to 0.169 and the $R_{c}$ of the different phenotypic traits was moderate or high (varied from 0.537 to 0.629 ) but the $R_{i}$ of phenotypic traits were low (varied from 0.279 to 0.361 ). In the high-density site, the PCV and GCV ranged from 0.054 to 0.150 , the repeatability of phenotypic traits was high (ranged from 0.598 to 0.869$)$, while the $R_{i}$ of $\mathrm{C} 1$ and $\mathrm{C} 2$ were low $(0.331$ and 0.443 , respectively). The repeatability of most phenotypic traits was a little higher than medium in the two sites, indicating that Eucalyptus was greatly affected by genetic effects and less affected by random environment. Moreover, all genetic parameters derived from UAV data were higher than the genetic parameters based on manual measurements (except the repeatability of $\mathrm{C} 2$ in the low-density site). Among the genetic parameters calculated 
from the metrics (i.e., $\mathrm{h}_{95}, \alpha, \mathrm{BI}$ ), the $P C V$ and $G C V$ ranged from 0.027 to 0.240 , and the repeatability ranged from 0.029 to 0.635 . The trends of $\mathrm{h}_{95}$ and $\mathrm{BI}$ are consistent with the trend of phenotypic traits, while the genetic parameters of $\alpha$ showed huge differences with phenotypic traits (Table 6).

Table 6. The genetic parameters of phenotypic traits and metrics in two sites.

\begin{tabular}{|c|c|c|c|c|c|c|c|c|c|}
\hline $\begin{array}{c}\text { Genetic } \\
\text { Parameters }\end{array}$ & H1 & H2 & DBH1 & DBH2 & $\mathrm{C} 1$ & $\mathrm{C} 2$ & $\mathbf{h}_{95}$ & $\alpha$ & BI \\
\hline \multicolumn{10}{|l|}{ Low-density site } \\
\hline$P C V$ & 0.112 & $0.118(5.1)$ & 0.125 & $0.128(2.4)$ & 0.122 & $\begin{array}{l}0.169 \\
(37.8)\end{array}$ & 0.149 & 0.240 & 0.057 \\
\hline GCV & 0.062 & $\begin{array}{l}0.071 \\
(14.5)\end{array}$ & 0.067 & $0.074(9.2)$ & 0.065 & $\begin{array}{l}0.089 \\
(37.3)\end{array}$ & 0.056 & 0.114 & 0.035 \\
\hline$R_{C}$ & 0.568 & $\begin{array}{l}0.629 \\
(10.9)\end{array}$ & 0.552 & $0.597(8.2)$ & 0.540 & $\begin{array}{l}0.537 \\
(-0.5)\end{array}$ & 0.328 & 0.465 & 0.635 \\
\hline$R_{i}$ & 0.305 & $\begin{array}{l}0.361 \\
(18.7)\end{array}$ & 0.291 & $\begin{array}{l}0.331 \\
(13.6)\end{array}$ & 0.281 & $\begin{array}{l}0.279 \\
(-0.8)\end{array}$ & 0.140 & 0.225 & 0.367 \\
\hline \multicolumn{10}{|c|}{ High-density site } \\
\hline$P C V$ & 0.082 & $0.088(6.8)$ & 0.066 & $0.070(5.9)$ & 0.101 & $\begin{array}{l}0.150 \\
(49.5)\end{array}$ & 0.097 & 0.158 & 0.081 \\
\hline GCV & 0.067 & $0.073(9.3)$ & 0.054 & $0.058(8.0)$ & 0.058 & $\begin{array}{l}0.100 \\
(72.8)\end{array}$ & 0.064 & 0.027 & 0.044 \\
\hline$R_{C}$ & 0.858 & $0.876(2.0)$ & 0.855 & $0.869(1.7)$ & 0.598 & $\begin{array}{l}0.705 \\
(17.8)\end{array}$ & 0.692 & 0.083 & 0.560 \\
\hline$R_{i}$ & 0.669 & $0.702(4.9)$ & 0.662 & $0.689(4.1)$ & 0.331 & $\begin{array}{l}0.443 \\
(33.6)\end{array}$ & 0.428 & 0.029 & 0.297 \\
\hline
\end{tabular}

Note: $P C V$ : phenotypic coefficient of variation, $G C V$ : genotypic coefficient of variation. The numbers in brackets are percentages of values calculated from manual measurements. H1, LiDAR manually measured tree height; H2, LiDAR extracted tree height; DBH1, LiDAR manually estimated DBH; DBH2, LiDAR estimated DBH; C1, orthophoto interpreted crown width; C2, LiDAR extracted crown width.

The results of comprehensive clonal evaluations were shown in Figure 8. The lower the value of $Q_{i}$, the higher the excellence of the clones. Five clones (i.e., $Q_{i 1}$ : JJ186, EC171, JJ122, EC174, JJ188; $\left.Q_{i 2}: J J 122, J J 186, E C 171, J J 188, E C 174\right)$ in the low-density site and three superior clones were selected (i.e., $Q_{i 1}$ : CM1615, EC248, CM1606; $Q_{i 2}$ : EC248, CM1615, CM1606) in the high-density site were selected as the superior clones with a $30 \%$ selection rate. The results of selecting superior Eucalyptus clones obtained by manual measurements and LiDAR extracted phenotypic traits were consistent. Furthermore, combined with the source information of Eucalyptus clones, the clones with superior phenotypic performance are: the pure clones (of E. urophylla) and the hybrid clones (of E. urophylla as female parent), and the hybrid clones (of E. urophylla and E. grandis) in low-density site, the hybrid clones (of E. urophylla as parents) and the hybrid clones (of E. urophylla and E. grandis) in high-density site (Figure 8).

We further estimated the genetic gains in phenotypic traits with different selection rates, the result showed that the difference of genetic gains between $\mathrm{H} 1$ and $\mathrm{H} 2$, DBH1 and $\mathrm{DBH} 2$ is small, while the difference between $\mathrm{C} 1$ and $\mathrm{C} 2$ is both larger in the two sites (Table 7). 
Table 7. Estimation of the genetic gains of superior clones within different selection rates in two sites.

\begin{tabular}{|c|c|c|c|c|c|c|c|}
\hline \multirow{2}{*}{$\begin{array}{c}\text { Selection } \\
\text { Rate }\end{array}$} & \multirow{2}{*}{$\begin{array}{c}\text { Number of } \\
\text { Entries }\end{array}$} & \multicolumn{6}{|c|}{ Genetic Gain (\%) } \\
\hline & & H1 & $\mathrm{H} 2$ & DBH1 & DBH2 & $\mathrm{C} 1$ & $\mathrm{C} 2$ \\
\hline \multicolumn{8}{|c|}{ Low-density site } \\
\hline $10 \%$ & 2 & 5.52 & 5.71 & 6.61 & 6.14 & 0.48 & 5.52 \\
\hline $20 \%$ & 3 & 5.07 & 5.63 & 5.96 & 6.21 & 1.45 & 3.03 \\
\hline $30 \%$ & 5 & 4.25 & 5.18 & 4.75 & 5.48 & 1.95 & 2.72 \\
\hline \multicolumn{8}{|c|}{ High-density site } \\
\hline $10 \%$ & 1 & 7.08 & 7.05 & 5.70 & 4.74 & 2.57 & 3.50 \\
\hline $20 \%$ & 2 & 6.82 & 6.64 & 5.61 & 4.39 & 0.44 & 1.53 \\
\hline $30 \%$ & 3 & 6.27 & 6.26 & 5.15 & 4.15 & 1.94 & 2.04 \\
\hline
\end{tabular}

Note: H1, LiDAR manually measured tree height; H2, LiDAR extracted tree height; DBH1, LiDAR manually estimated DBH; DBH2, LiDAR estimated DBH; C1, orthophoto interpreted crown width; C2, LiDAR extracted crown width.

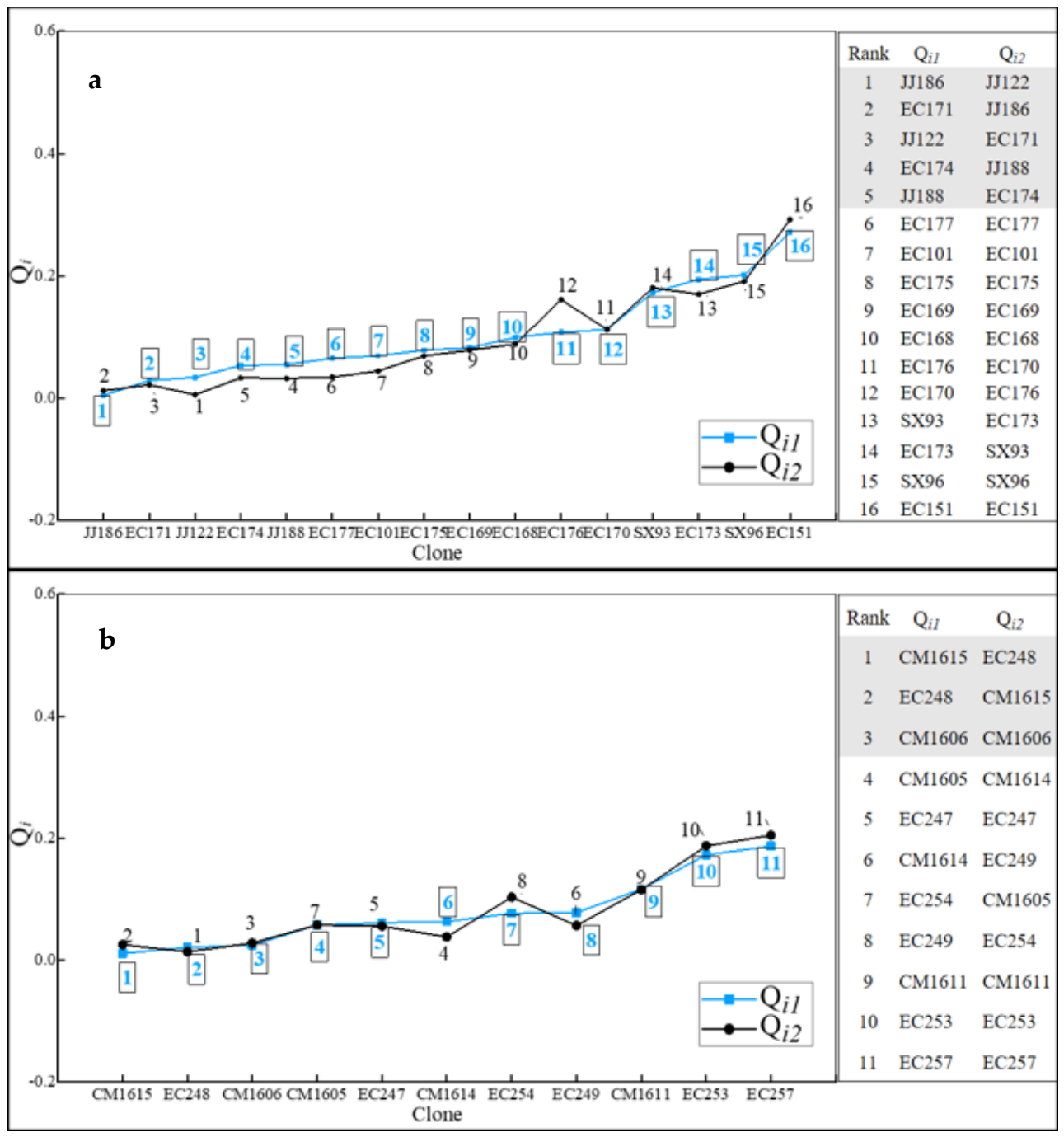

Figure 8. Evaluation and ranking of Eucalyptus clones in two sites. $(\mathbf{a}, \mathbf{b})$ were the results of site- 1 and site-3 separately. The number on the broken line is the ranking of the evaluation index $Q_{i}$ value of a clone from small to large; $Q_{i 1}$ is calculated from manual measurements $(\mathrm{H} 1, \mathrm{DBH} 1$ and $\mathrm{C} 1)$, and $Q_{i 2}$ is calculated from LiDAR extracted phenotypic traits (i.e., $\mathrm{H} 2$, DBH2 and C2).

\section{Discussion}

As rapidly evolving in the field of high-throughput phenotyping, greater progress is needed in areas of multi-source phenotypic data extraction and applications aimed at 
increasing genetic gain and shortening breeding cycle [7]. In this study, the UAV-based high-throughput phenotyping was applied to the breeding study of Eucalyptus trials for the first time, we extracted the high-throughput phenotypic data based on UAV LiDAR point clouds and UAV high-resolution images and then compared with the manually obtained phenotype for genetic differences analysis. The results revealed the potential and feasibility of novel UAV remote sensing technology in the acquisition and analysis of high-throughput phenotypic traits.

\subsection{Individual Tree Segmentation}

The individual tree segmentation effects of MWS and PCS were evaluated in the Eucalyptus trials. The stem density and canopy overlap have a decisive influence on the extraction accuracy and segmentation effect [68,69], Guo et al. (2016) [70] conducted a study of individual tree segmentation in broad-leaved forests with different stem densities based on the MWS. Results showed that the $r, p$ and $F$ are $0.80,0.97,0.88$, respectively, in the sparse forest and $0.63,0.68,0.66$, respectively, in dense forest. Bai et al. (2020) [71] studied the accuracy of individual tree segmentation in four different forest types (i.e., coniferous forest, broad-leaved forest, coniferous broad-leaved forest and virgin forest) and the results showed that the PCS based on point cloud has better applicability and precision in coniferous forests $(r=0.70, p=0.88)$ than other approaches.

The three sites in this study are broad-leaved forests with closed and tightly arranged canopies. The greater the stem density, the smaller the average crown width of the three sites. The overall accuracy (F) of MWS and PCS was similar in site-1 with the low stem density and roughly arranged canopy, but the segmentation effect differed as the $r$ value of MWS was lower than PCS. This may be due to the phenomenon of crown overlap being less in low-density site-1, therefore the local maximum is usually identified as the top of a tree when using the MWS method; besides, some of the shorter and smaller trees which were excessively smoothened by CHM were gathered into a larger tree overlapped around, reducing the over-segmentation phenomenon relatively. In sites 2 and 3, with the larger stem density with neatly arranged canopies but the increasing overlapping phenomena between canopies in each row, both MWS and PCS overestimated the number of trees which subsequently gave rise to the low overall accuracy. Compared with PCS, MWS revealed less instances of the over segmentation phenomenon and a stronger adaptability on site-2 and site-3. PCS showed a lower $p$ value than $r$ value in the three sites. This results were similar to those obtained by Wu et al. (2019) [72], whose research extracted individual trees by adopting PCS in Ginkgo-planted forests with stem density 713 n/ha subsequently showing that the $\mathrm{p}$ value of PCS was lower than the $r$ value. There may be some factors such as the significant differences of tree crowns, the large number of trunk branches and the overlapping phenomenon, rendering it difficult to set an appropriate distance threshold for PCS, resulting in the over-segmentation phenomenon in higher density sites, the overall segmentation accuracy $(F)$ of PCS is therefore lower than MWS in higher-density forests.

\subsection{Statistical Analysis}

The result of scatter plots showed that there was a high correlation between tree heights from different sources indicated that the LiDAR extracted tree height can well describe the actual tree height of Eucalyptus, which was also reflected in previous studies [73,74]. The DBH derived from the optimal $\mathrm{DBH}-\mathrm{H}$ regression model has a high correlation with $\mathrm{H}$, the fitting accuracy between DBH1 and DBH2 thereby was higher. Tree height and $\mathrm{DBH}$ maintained high consistency in the estimations of genetic parameters and genetic gain. Owing to the overlapping phenomenon in addition to the excessive corrected crown shape and height of individual trees by the smoothened CHM, the correlation between $\mathrm{C} 1$ and $\mathrm{C} 2$ was low and the error among them was large, affecting the comparison of genetic parameters between manual measurements and LiDAR extracted phenotypic traits.

The clones not only inherit the additive effect of the parent tree, but also inherit the dominant and epistatic effects of the parent tree, which can obtain the greatest genetic 
gain and maintain the stability of traits. Significant differences of phenotypic traits are observed at a clonal level, which showed good potential for superior clone selection of Eucalyptus. UAV-based remote sensing data showed its potential in tree breeding as the LiDAR extracted phenotypic traits (i.e., H2, DBH2, C2) among clones were significantly different indicating there was genetic differentiation which was similar with manual measurements (i.e., H2, DBH2, C2), highlighting the feasibility of UAV remote sensing for forest phenotyping [75]. Moreover, it seems that a number of functional traits related to LiDAR metrics and vegetation indices are different among clones but demand further study. Previous studies verified the correlation, Santini et al. (2019) [33] used UAV-borne remote sensing technology for phenotyping of forest genetic trials showed that there were genetic divergences in various spectral and morphological characteristics related to volume in the Pinus halepensis, reflecting that the characteristics of canopy among populations had a strong impact on the aboveground growth of Pinus halepensis. Francois et al. (2020) [76] utilized the UAV borne LiDAR data to assess the performance of genetic improvement across three genetic levels and three stand spacings, thus resulting in findings that genetically superior trees were typically taller, with higher, shorter and denser crowns. In this study, most of LiDAR-Metrics (47/57) and visible vegetation indices (26/27) showed significant difference $(\mathrm{P}<0.05)$ across clones, however, most LiDAR Metrics and vegetation indices had a weak correlation with phenotypic traits, which may be influenced by erroneous crown boundaries, mutual shading between canopies and the canopy shadows.

\subsection{Genetic Characteristic and Clone Evaluation}

The trial and selection of clones including the clone experiments, the estimation of genetic parameters and the evaluation of clones represent important means for genetic improvement. Estimation of phenotypic coefficients of variations (PCVs), genotypic coefficients of variations (GCVs) and repeatability is necessary for selecting superior clones for specific or large-scale areas across environments $[77,78]$. In this study, the PCVs and GCVs of different phenotypic traits based on manual measurements and LiDAR extraction ranged from 0.054 to 0.169 , which showed a low or moderate variance according to Meena et al. [79]. Relative to estimates based on manual measurements (i.e., H1, DBH1, $\mathrm{C} 1$ ), the $R_{C}$ of phenotype traits based on LiDAR point cloud (i.e., H2, DBH2, C2) were overestimated except for the repeatability of crown width in the low-density site. These results differ from the genetic field trial of a 12-year-old clonal Norway Spruce which showed that heritability values calculated based on the UAV system were underestimated and overestimated for height and diameter separately, but use of the more sophisticated UAV system could significantly improve results of the genetic trial [80]. In this study, the genetic parameters of the LiDAR Metrics (i.e., $\mathrm{h}_{95}, \alpha$ ) and visible vegetation indices (i.e., BI) were further calculated to explore the genetic parameter analysis from a different perspective with UAV-based data, and their trend of changes are consistent with the genetic parameters of tree height and DBH except $\alpha$ closely related to the spatial distribution of tree crowns.

The crown width was considered as one of the factors in clonal evaluation but assigned a low weight due to the cultivated goal aimed to select industrial materials with high adaptability and yields in this trial. The ranking of evaluation indexes $Q_{i 1}$ and $Q_{i 2}$ were not completely consistent which may most likely be due to the influence of the crown width. However, among the two sites, the pure clones (of E. urophylla), the hybrid clones (of E. urophylla as female parent) and the hybrid clones (of E. wetarensis and E. grandis) had higher superiority than others, which was also reflected in previous studies. Cao et al. (2012) [81] found that hybrid clones with E. urophylla as parents had better growth performance and survivals rate and it might obtain good results from employing E. urophylla and E. grandis as parents for hybridization. The heterosis test from Chen et al. (2017) [82] in GuangXi found that the hybrid families with E. grandis, E. camaldulensis, E. wetarensis and E. tereticornis as male parent and E. urophyllas as the female parent have heterosis. UAV high-throughput technology might be an efficient alternative for the selection of superior variety and reducing costs in the breeding programs. 
In this study, we applied the high-throughput phenotyping combined with UAV-based data to the breeding research of Eucalyptus trials, providing hopefully a reference processing procedure and data support based on UAV remote sensing data for phenotypic analysis in tree breeding. Conducting high-throughput phenotyping requires the extraction of highthroughput data phenotype traits at an individual tree scale. The two prevailing LiDARbased individual tree segmentation methods were compared in this study, but methods to choose or establish a high-precision approach of individual tree acquisition need to be constantly studied. Some approaches (e.g., to combine the structural characteristics of point clouds and spectral characteristics of raster images, etc.) can be implemented to attempt improvement of the accuracy of detection in other forest with different forest characteristics $[83,84]$. Making full use of high-density LiDAR point cloud data and UAVRGB orthophoto to obtain high-throughput information about forest structural and spectral characteristics is an effective and low-cost method, however, the UAV borne equipment with higher quality (e.g., multispectral, hyperspectral, fluorescence and thermal infrared, etc.) are expected to collect all-round, multi-scale and multi-dimensional high-throughput phenotypic data, helping analyze the phenotypic inheritance and genetic variation and the response to biological and abiotic stresses of forest trees. Additionally, it can aid with monitoring of forest trees with whole growth periods continually and different forest trees in multi-sites to reveal the expression mechanism of different genotypes interacting with the environment, as well as reveal the geographical pattern of population genetic variation in large-scale research to further improve the genotype selection result $[80,85,86]$. Furthermore, the combination of high-throughput phenotypic data, QTLS (Quantitative Trait Loci) and GWAS (Genome Wide Association Analysis) would further extract and determine the function of genes, which can not only shorten the breeding cycle and greatly improve the efficiency of tree breeding, but can also shed new light on the genetic principles of important phenotypic traits to select and cultivate superior tree species with higher yield, better quality, stronger stress resistance and wider adaptability.

\section{Conclusions}

In this study, the high-throughput phenotyping combined with UAV-based data was applied to the genetic characteristic analysis of Eucalyptus clones aimed at exploring the effectiveness of the UAV technology for phenotypic analysis of forest trees. The individual tree segmentation method MWS performed better than PCS overall and the difference of overall accuracy between them gradually expanded with an increase of stem density. UAVLiDAR extracted phenotypic traits and manual measurements were significantly different across the Eucalyptus clones, as too were most of structural metrics and spectral indices, reflecting the genetic divergences between the clones. Clone rankings obtained were similar with both high-throughput phenotyping derived from UAV-based data and phenotyping on manual measurements. The UAV-based remote sensing technology provided great advantages and potential of high-throughput phenotypic traits acquisition and contributed novel insights of the genetic analysis.

Author Contributions: L.L. wrote the original manuscript, performed the methods and experiments, analyzed the data and validated the results; L.C. conceived and designed the experiments; L.C., Y.X., J.L. and G.W. edited the manuscript. All authors have read and agreed to the published version of the manuscript.

Funding: This research was funded by the National Natural Science Foundation of China (31922055) and the Priority Academic Program Development of Jiangsu Higher Education Institutions (PAPD).

Acknowledgments: The authors gratefully acknowledge the foresters in Gaofeng Forest for their assistance with data collection and sharing their experiences of the local forests. We also would like to thank the graduate students from the department of forest management and silviculture at Nanjing Forestry University for helping in data collection and providing suggestions for improving this study.

Conflicts of Interest: The authors declare no conflict of interest. 


\section{Appendix A}

Table A1. Information of Eucalyptus Clones.

\begin{tabular}{|c|c|c|c|c|c|}
\hline Site & Number & Species & Site & Number & Species \\
\hline \multirow{16}{*}{1} & EC176 & $\begin{array}{l}\text { E. wetarensis } \times(\text { E. urophylla } \times E \text {. } \\
\text { wetarensis })\end{array}$ & \multirow{16}{*}{2} & EC194 & E. urophylla $\times$ E. pellita \\
\hline & EC168 & E. wetarensis $\times$ E. grandis & & EC196 & E. urophylla $\times$ E. pellita \\
\hline & EC173 & E. wetarensis $\times$ E. pellita & & EC197 & E. urophylla $\times$ E. pellita \\
\hline & EC177 & E. wetarensis $\times$ E. pellita & & EC200 & E. urophylla $\times$ E. pellita \\
\hline & EC170 & E. wetarensis $\times$ E. pellita & & EC189 & E. urophylla $\times$ E. camaldulensi \\
\hline & JJ122 & E. urophylla $\times$ E. wetarensis & & JJ1402 & E. urophylla \\
\hline & EC174 & E. urophylla & & JJ1409 & E. urophylla \\
\hline & EC175 & E. urophylla & & JJ1410 & E. urophylla \\
\hline & JJ186 & E. urophylla & & $\mathrm{JJ} 2280$ & E. urophylla \\
\hline & JJ188 & E. urophylla & & EC182 & E. grandis $\times$ E. urophylla \\
\hline & EC151 & E. wetarensis $\times$ E. grandis & & GL9 & E. grandis $\times$ E. urophylla \\
\hline & EC171 & E. wetarensis $\times$ E. grandis & & EC184 & E. grandis $\times E$. grandis \\
\hline & EC101 & E. wetarensis $\times$ E. pellita & & EC185 & E. grandis $\times E$. grandis \\
\hline & EC169 & E. wetarensis $\times$ E. pellita & & EC195 & E. pellita $\times$ E. urophylla \\
\hline & SX93 & E. camaldulensi & & EC199 & E. pellita $\times$ E. grandis \\
\hline & SX96 & E. camaldulensi & & SX95 & E. camaldulensi \\
\hline \multirow{11}{*}{2} & EC180 & E. wetarensis $\times$ E. urophylla & \multirow{11}{*}{3} & EC247 & E. wetarensis $\times$ E. urophylla \\
\hline & EC188 & E. wetarensis $\times$ E. grandis & & EC249 & E. urophylla $\times$ E. wetarensis \\
\hline & EC198 & E.wetarensis $\times$ E. pellita & & CM1605 & E. urophylla $\times E . A B L$ \\
\hline & 3229 & E. urophylla $\times$ E. grandis & & CM1606 & E. urophylla $\times E . A B L$ \\
\hline & EC181 & E. urophylla $\times$ E. grandis & & CM1611 & E. urophylla $\times E . A B L$ \\
\hline & EC186 & E. urophylla $\times$ E. pellita & & CM1614 & E. urophylla $\times E . A B L$ \\
\hline & EC187 & E. urophylla $\times$ E. pellita & & CM1615 & E. urophylla $\times E . A B L$ \\
\hline & EC190 & E. urophylla $\times$ E. pellita & & EC254 & $\begin{array}{l}\text { E. wetarensis } \times(\text { E. urophylla* } E \text {. } \\
\text { pellita) }\end{array}$ \\
\hline & EC191 & E. urophylla $\times$ E. pellita & & EC248 & E. wetarensis $\times$ E. grandis \\
\hline & EC192 & E. urophylla $\times$ E. pellita & & EC253 & E. wetarensis $\times$ E. grandis \\
\hline & EC193 & E. urophylla $\times$ E. pellita & & EC257 & E. wetarensis \\
\hline
\end{tabular}


Table A2. F-value and significance level of ANOVAs for LiDAR metrics and vegetation index (VI) in three sites.

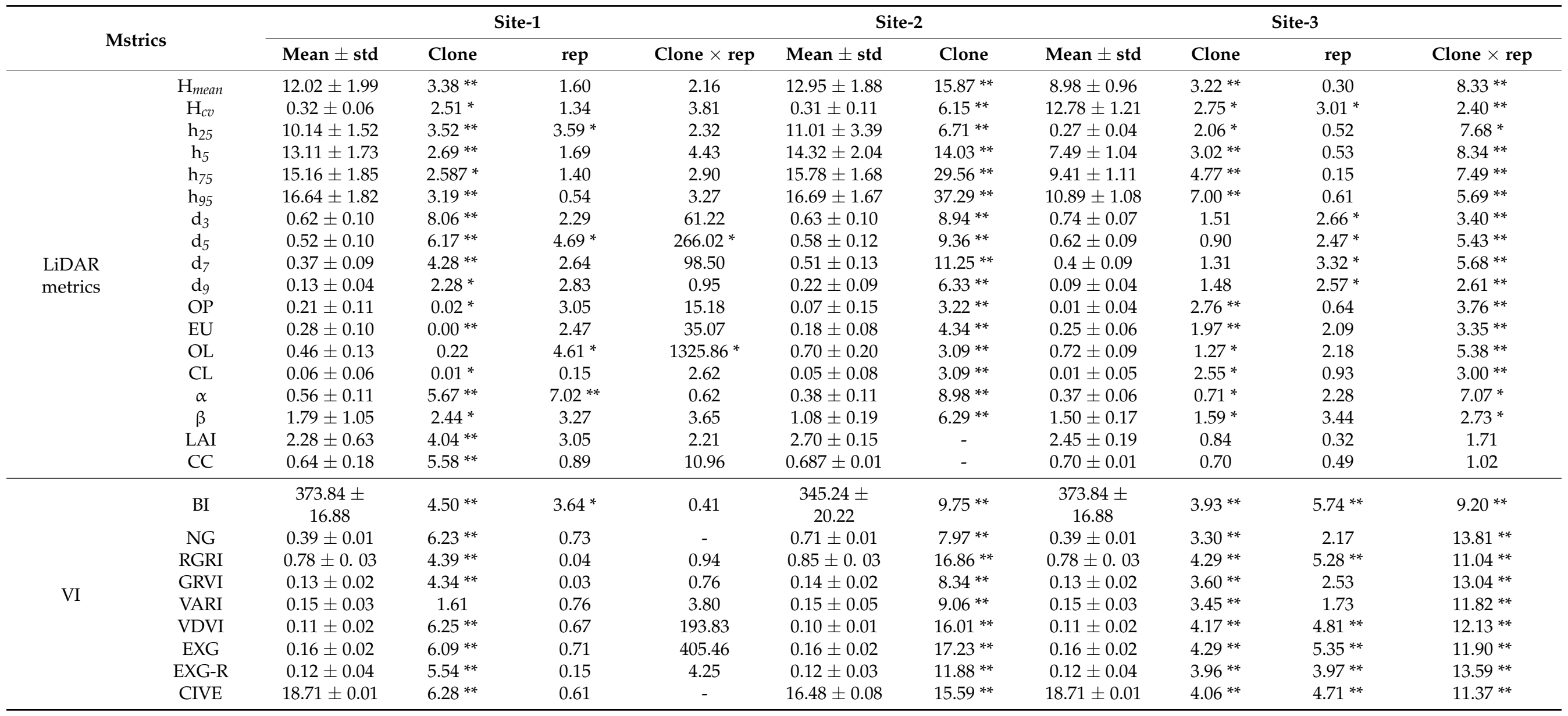

Note: *: significant difference $(\mathrm{P}<0.05)$; **: extremely significant difference $(\mathrm{P}<0.01)$. 
Table A3. Pearson's correlations between phenotypic traits and LiDAR metrics and vegetation index in three sites.

\begin{tabular}{|c|c|c|c|c|c|c|c|c|c|c|c|c|c|c|c|c|c|c|c|}
\hline \multirow{2}{*}{\multicolumn{2}{|c|}{ Correlation }} & \multicolumn{6}{|c|}{ Site-1 } & \multicolumn{6}{|c|}{ Site-2 } & \multicolumn{6}{|c|}{ Site-3 } \\
\hline & & H1 & H2 & D1 & D2 & $\mathrm{C} 1$ & C2 & H1 & $\mathrm{H} 2$ & D1 & D2 & $\mathrm{C} 1$ & C2 & H1 & H2 & D1 & D2 & $\mathrm{C} 1$ & C2 \\
\hline \multirow{5}{*}{ Traits } & H1 & & $0.95 * *$ & $0.99 * *$ & $0.95^{* *}$ & $0.52 * *$ & $0.48 * *$ & & $0.99 * *$ & $1.00 * *$ & $0.99 * *$ & $0.22 * *$ & $0.26^{* *}$ & & $0.96^{* *}$ & $0.98^{* *}$ & $0.96 * *$ & 0.25 ** & $0.35^{* *}$ \\
\hline & $\mathrm{H} 2$ & $0.95^{* *}$ & & $0.95^{* *}$ & $0.99 * *$ & $0.57^{* *}$ & $0.53 * *$ & $0.99 * *$ & & $0.99 * *$ & $1.00 * *$ & $0.22^{* *}$ & 0.27 ** & $0.96^{* *}$ & & $0.96^{* *}$ & $1.00^{* *}$ & $0.24^{* *}$ & 0.34 ** \\
\hline & D1 & $0.99 * *$ & $0.95^{* *}$ & & $0.95 * *$ & 0.52 ** & 0.48 ** & $1.00 * *$ & $0.99^{* *}$ & & $0.99 * *$ & $0.22 * *$ & 0.26 ** & 1.00 ** & $0.96^{* *}$ & & $0.96 * *$ & 0.25 ** & 0.35 ** \\
\hline & $\mathrm{C} 1$ & 0.52 ** & $0.57^{* *}$ & 0.52 ** & 0.56 ** & & $0.80^{* *}$ & 0.22 ** & 0.22 ** & 0.22 ** & $0.68 * *$ & & $0.74 * *$ & 0.25 ** & $0.24^{* *}$ & $0.25 * *$ & $0.24 * *$ & & 0.63 ** \\
\hline & $\mathrm{C} 2$ & $0.48^{* *}$ & $0.53 * *$ & $0.48^{* *}$ & $0.53^{* *}$ & $0.80^{* *}$ & & $0.26^{* *}$ & $0.27^{* *}$ & 0.26 ** & $0.92 * *$ & $0.74^{* *}$ & & 0.35 ** & $0.34^{* *}$ & 0.35 & 0.34 & $0.63^{\text {** }}$ & \\
\hline \multirow{16}{*}{$\begin{array}{l}\text { LiDAR } \\
\text { metrics }\end{array}$} & $\mathrm{H}_{\text {mean }}$ & 0.76 ** & $0.77^{* *}$ & $0.52 * *$ & 0.37 ** & $0.16^{* *}$ & $0.17^{* *}$ & 0.68 ** & $0.69 * *$ & $0.39 * *$ & $0.18 * *$ & 0.03 & $-0.12 *$ & $0.80^{* *}$ & $0.84^{* *}$ & $0.51 * *$ & $0.37 * *$ & 0.10 & 0.02 \\
\hline & $\mathrm{H}_{c v}$ & 0.23 ** & $0.21 * *$ & $0.24 * *$ & $0.30^{* *}$ & 0.28 ** & $0.19 * *$ & 0.03 & 0.04 & 0.02 & $0.21 * *$ & 0.02 & $0.25^{* *}$ & $0.14 *$ & $0.12 *$ & 0.00 & $0.23 * *$ & -0.09 & $0.22^{* *}$ \\
\hline & $h_{25}$ & 0.43 ** & $0.46^{* *}$ & $0.25 * *$ & 0.11 & -0.03 & 0.03 & $0.35^{* *}$ & $0.04^{* *}$ & $0.18^{* *}$ & -0.02 & -0.02 & $-0.21^{* *}$ & $0.63^{* *}$ & $0.66^{* *}$ & 0.43 ** & 0.23 ** & $0.13^{*}$ & -0.06 \\
\hline & $\mathrm{h}_{75}$ & 0.90 ** & $0.90^{* *}$ & 0.65 ** & 0.51 ** & 0.28 ** & $0.27 * *$ & 0.94 ** & 0.95 ** & 0.56 ** & $0.44 * *$ & 0.08 & 0.06 & $0.90^{* *}$ & $0.93^{* *}$ & $0.57 * *$ & $0.47 * *$ & 0.07 & 0.10 \\
\hline & $\mathrm{h}_{95}$ & $0.99 * *$ & $0.95^{* *}$ & 0.69 ** & 0.68 ** & 0.46 ** & $0.29 * *$ & $0.99 * *$ & $0.99 * *$ & 0.66 ** & 0.58 ** & $0.18^{* *}$ & $0.22 * *$ & 0.94 ** & $0.99^{* *}$ & $0.57 * *$ & 0.58 ** & 0.08 & $0.20^{* *}$ \\
\hline & $\mathrm{d}_{3}$ & 0.20 ** & $0.17^{* *}$ & 0.06 & 0.12 & 0.09 & -0.05 & 0.08 & 0.08 & 0.06 & $-0.15^{* *}$ & 0.02 & -0.23 ** & $0.13 *$ & $0.14 *$ & $0.22 * *$ & -0.08 & $0.20^{* *}$ & $-0.17^{* *}$ \\
\hline & $\mathrm{d}_{5}$ & 0.08 & 0.09 & -0.04 & -0.08 & -0.12 & $-0.13^{*}$ & 0.10 & 0.10 & 0.04 & $-0.20 * *$ & -0.03 & $-0.30^{* *}$ & $0.18^{* *}$ & $0.18^{* *}$ & 0.20 ** & $-0.14^{*}$ & $0.13 *$ & $-0.27^{* *}$ \\
\hline & $d_{7}$ & 0.03 & 0.09 & -0.03 & $-0.22 * *$ & $-0.28^{* *}$ & -0.11 & 0.10 & 0.10 & -0.03 & $-0.28^{* *}$ & -0.11 * & $-0.40^{* *}$ & $0.16^{* *}$ & $0.16^{* *}$ & $0.17^{* *}$ & $-0.20^{* *}$ & 0.10 & $-0.34^{* *}$ \\
\hline & $\mathrm{d}_{9}$ & 0.06 & 0.137 * & 0.04 & $-0.27^{* *}$ & $-0.36^{* *}$ & -0.05 & 0.01 & 0.02 & $-0.24^{* *}$ & $-0.46^{* *}$ & $-0.34^{* *}$ & $-0.57^{* *}$ & 0.07 & 0.08 & 0.03 & $-0.25 * *$ & -0.02 & $-0.36^{* *}$ \\
\hline & $\mathrm{OP}$ & $0.30^{* *}$ & $0.23 * *$ & 0.35 ** & $0.49^{* *}$ & $0.51^{* *}$ & $0.32^{* *}$ & -0.01 & -0.01 & $0.31^{* *}$ & $0.48^{* *}$ & $0.42^{* *}$ & $0.60^{* *}$ & 0.08 & 0.08 & $0.14 *$ & $0.32 * *$ & 0.11 & $0.36^{* *}$ \\
\hline & $\mathrm{EU}$ & -0.19 ** & $-0.16^{* *}$ & $-0.15^{*}$ & $-0.12 *$ & -0.11 & -0.11 & -0.02 & -0.03 & 0.07 & $0.20 * *$ & $0.12 *$ & $0.27^{* *}$ & $-0.02 * *$ & $-0.14^{*}$ & $-0.15^{* *}$ & 0.09 & -0.08 & $0.19^{* *}$ \\
\hline & $\mathrm{OL}$ & $-0.16^{* *}$ & $-0.12 *$ & $-0.21^{* *}$ & $-0.33^{* *}$ & -0.34 ** & $-0.21^{* *}$ & 0.01 & 0.02 & $-0.34 * *$ & $-0.54 * *$ & $-0.48^{* *}$ & $-0.68^{* *}$ & 0.06 & 0.05 & 0.00 & $-0.30 * *$ & -0.03 & $-0.40^{* *}$ \\
\hline & CL & 0.07 & 0.07 & 0.05 & 0.02 & 0.00 & 0.02 & 0.01 & 0.00 & $0.22 * *$ & $0.28^{* *}$ & $0.29^{* *}$ & $0.34^{* *}$ & 0.01 & 0.00 & 0.06 & $0.14^{*}$ & 0.05 & $0.17^{* *}$ \\
\hline & $\alpha$ & $-0.38^{* *}$ & $-0.49^{* *}$ & -0.21 & $-0.38^{* *}$ & 0.02 & -0.28 & -0.06 & -0.07 & 0.08 & 0.33 ** & $0.15^{* *}$ & $0.44^{* *}$ & -0.03 & -0.02 & -0.10 & $0.28^{* *}$ & -0.10 & 0.37 ** \\
\hline & $\beta$ & $-0.50^{* *}$ & $-0.55^{* *}$ & $-0.44^{* *}$ & $-0.44^{* *}$ & -0.22 & -0.31 * & $-0.12^{*}$ & 0.00 & $0.16^{* *}$ & 0.35 ** & 0.31 ** & 0.51 ** & -0.15 ** & -0.15 ** & -0.07 & 0.21 ** & 0.01 & 0.35 ** \\
\hline & LAI & 0.24 & $0.37^{* *}$ & 0.10 & $0.40^{* *}$ & -0.06 & $0.36^{*}$ & 0.24 & $-0.14^{*}$ & 0.21 * & 0.21 & -0.05 & 0.32 & $0.26^{*}$ & $0.29 *$ & 0.14 & $0.37 * *$ & -0.11 & 0.35 ** \\
\hline \multirow{9}{*}{ VI } & BI & $0.21^{* *}$ & $0.25^{* *}$ & $0.21^{* *}$ & 0.06 & 0.00 & $0.13 *$ & -0.08 & -0.07 & 0.05 & 0.08 & $0.12 *$ & $0.14^{*}$ & -0.04 & -0.03 & -0.05 & $0.13 *$ & -0.03 & $0.19^{* *}$ \\
\hline & NG & 0.10 & 0.10 & 0.12 & $0.126^{*}$ & $0.121 *$ & 0.08 & 0.08 & 0.08 & 0.01 & 0.07 & -0.04 & 0.06 & 0.07 & 0.07 & $-0.16^{* *}$ & $0.26 * *$ & $-0.25^{* *}$ & $0.29 * *$ \\
\hline & RGRI & 0.09 & 0.11 & 0.05 & -0.03 & -0.08 & 0.01 & $-0.19^{* *}$ & $-.19^{* *}$ & 0.03 & -0.04 & $0.17^{* *}$ & 0.04 & -0.05 & -0.04 & $0.20^{* *}$ & -0.30 ** & $0.29^{* *}$ & $-0.35 * *$ \\
\hline & GRVI & -0.10 & -0.12 & -0.06 & 0.03 & 0.07 & -0.01 & -0.08 & -0.08 & 0.00 & -0.07 & 0.04 & -0.05 & -0.08 & -0.07 & 0.15 ** & $-0.26^{* *}$ & 0.25 ** & $-0.29^{* *}$ \\
\hline & VARI & $-0.16^{* *}$ & $-0.18^{* *}$ & -0.11 & 0.00 & 0.06 & -0.04 & 0.07 & 0.06 & 0.00 & 0.00 & -0.05 & -0.05 & -0.10 & -0.09 & $0.12 *$ & $-0.24^{* *}$ & 0.22 ** & $-0.25 * *$ \\
\hline & VDVI & 0.10 & 0.10 & 0.12 & $0.127^{*}$ & $0.121^{*}$ & 0.08 & $-0.18^{* *}$ & $-0.18^{* *}$ & 0.05 & -0.03 & $0.19^{* *}$ & 0.05 & -0.05 & -0.04 & $0.19^{* *}$ & $-0.30^{* *}$ & $0.29 * *$ & $-0.35^{* *}$ \\
\hline & EXG & 0.10 & 0.10 & 0.12 & $0.126^{*}$ & 0.120 * & 0.08 & $-0.18^{* *}$ & $-0.18^{* *}$ & 0.05 & -0.03 & 0.19 ** & 0.06 & -0.05 & -0.04 & 0.20 ** & $-0.30 * *$ & $0.29 * *$ & $-0.35^{* *}$ \\
\hline & EXGR & 0.01 & 0.00 & 0.04 & 0.08 & 0.10 & 0.04 & $-0.15^{* *}$ & $-0.15^{* *}$ & 0.03 & -0.05 & $0.14 *$ & 0.01 & -0.06 & -0.05 & $0.18^{* *}$ & $-0.29 * *$ & $0.28 * *$ & $-0.33^{* *}$ \\
\hline & CIVE & -0.09 & -0.09 & -0.11 & $-0.12 *$ & -0.12 & -0.07 & $0.18^{* *}$ & $0.18^{* *}$ & -0.06 & 0.03 & $-0.19^{* *}$ & -0.04 & 0.05 & 0.04 & $-0.20^{* *}$ & $0.30 * *$ & $-0.29^{* *}$ & $0.35^{* *}$ \\
\hline
\end{tabular}

Note: *: significant correlations $(\mathrm{P}<0.05)$; ${ }^{* *}$ : extremely significant correlations $(\mathrm{P}<0.01)$. 


\section{References}

1. Zhou, J.; Tardieu, F.; Pridmore, T.; Doonan, J.; Reynolds, D.; Hall, N.; Griffiths, S.; Cheng, T.; Zhu, Y.; Wang, X.; et al. Plant phenomics: History, present status and challenges. J. Nanjing Agric. Univ. 2018, 41, 580-588. [CrossRef]

2. Dungey, H.S.; Dash, J.P.; Pont, D.; Clinton, P.W.; Watt, M.S.; Telfer, E.J. Phenotyping Whole Forests Will Help to Track Genetic Performance. Trends Plant Sci. 2018, 23, 854-864. [CrossRef]

3. Pan, Y. Analysis of Concepts, Categories of Plant Phenome and Phenomics. Acta Agron. Sin. 2015, 41, 175-186. [CrossRef]

4. Fiorani, F.; Schurr, U. Future scenarios for plant phenotyping. Annu. Rev. Plant Biol. 2013, 64, 267-291. [CrossRef]

5. Bian, L.; Zhang, H. Application of Phenotyping Techniques in Forest Tree Breeding and Precision Forestry. Sci. Silvae Sin. 2020, 56, 113-126. [CrossRef]

6. Rincent, R.; Charpentier, J.; Faivre-Rampant, P.; Paux, E.; Le Gouis, J.; Bastien, C.; Segura, V. Phenomic Selection Is a Low-Cost and High-Throughput Method Based on Indirect Predictions: Proof of Concept on Wheat and Poplar. G3 2018, 8, $3961-3972$. [CrossRef] [PubMed]

7. Araus, J.L.; Kefauver, S.C.; Zaman-Allah, M.; Olsen, M.S.; Cairns, J.E. Translating High-Throughput Phenotyping into Genetic Gain. Trends Plant Sci. 2018, 23, 451-466. [CrossRef] [PubMed]

8. Matese, A.; Toscano, P.; Di Gennaro, S.; Genesio, L.; Vaccari, F.; Primicerio, J.; Belli, C.; Zaldei, A.; Bianconi, R.; Gioli, B. Intercomparison of UAV, Aircraft and Satellite Remote Sensing Platforms for Precision Viticulture. Remote Sens. 2015, 7, $2971-2990$. [CrossRef]

9. Kang, X. Research progress and prospect of forest genetics and tree breeding. J. Nanjing For. Univ. Nat. Sci. Ed. 2020, 44, 1-10.

10. Zhao, C. Big Data of Plant Phenomics and Its Research Progress. J. Agric. Big Data 2019, 1, 5-18. [CrossRef]

11. Appels, R. Plant phenome to genome: A mini-review. Funct. Plant Biol. 2012, 39, iii-viii. [CrossRef]

12. Li, X.; Li, Q.; Lyu, L.; Lan, S. Economic Benefit Analysis of 6-year-old Eucalypt Plantation in Guangxi State-owned Gaofeng Forest Farm. Guangxi For. Sci. 2020, 49, 613-617. [CrossRef]

13. Wu, Q.; Zhang, Y.; Tao, R.; Zhu, Y.; Lan, S. Limitation and Its Comprehensive Measures of High-sustainable Production in Eucalyptus Plantation, Guangxi Province. J. Anhui Agric. Sci. 2020, 48, 125-130. [CrossRef]

14. Wen, Y.; Zhou, X.; Yu, S.; Zhu, H. The Predicament and Countermeasures of Development of Global Eucalyptus Plantations. Guangxi Sci. 2018, 25, 107-116. [CrossRef]

15. Zhang, L.; Xiong, T.; Wang, J.; Shi, Q.; Li, L.; Chen, D.; Tang, Z.; Lan, J. Eucalyptus Clonal Breeding at Guangxi Dongmen Forest Farm. Eucalypt Sci. Technol. 2015, 32, 45-49. [CrossRef]

16. Guo, Q.; Wu, F.; Pang, S.; Zhao, X.; Chen, L.; Liu, J.; Xue, B.; Xu, G.; Li, L.; Jing, H.; et al. Crop 3D: A platform based on LiDAR for 3D high-throughput crop phenotyping. Sci. Sin. 2016, 46, 1210-1221. [CrossRef]

17. Pieruschka, R.; Poorter, H. Phenotyping plants: Genes, phenes and machines. Funct. Plant Biol. 2012, 39, 813. [CrossRef] [PubMed]

18. Houle, D.; Govindaraju, D.R.; Omholt, S. Phenomics: The next challenge. Nat. Rev. Genet. 2010, 11, 855-866. [CrossRef]

19. Cabrera-Bosquet, L.; Crossa, J.; von Zitzewitz, J.; Serret, M.D.; Luis Araus, J. High-throughput Phenotyping and Genomic Selection: The Frontiers of Crop Breeding Converge. J. Integr. Plant Biol. 2012, 54, 312-320. [CrossRef]

20. Xie, C.; Yang, C. A review on plant high-throughput phenotyping traits using UAV-based sensors. Comput. Electron. Agric. 2020, 178, 105731. [CrossRef]

21. Pang, Y.; Li, Z.; Chen, E.; Sun, G. Lidar Remote Sensing Technology and Its Application in Forestry. Sci. Silvae Sin. 2005, 41, 129-136. [CrossRef]

22. Dubayah, R.O.; Sheldon, S.L.; Clark, D.B.; Hofton, M.A.; Blair, J.B.; Hurtt, G.C.; Chazdon, R.L. Estimation of tropical forest height and biomass dynamics using lidar remote sensing at La Selva, Costa Rica. JGR J. Geophys. Res. Biogeosci. 2010, 115. [CrossRef]

23. Parker, G.G.; Harmon, M.E.; Lefsky, M.A.; Chen, J.; Pelt, R.V.; Weis, S.B.; Thomas, S.C.; Winner, W.E.; Shaw, D.C.; Frankling, J.F. Three-dimensional Structure of an Old-growth Pseudotsuga-Tsuga Canopy and Its Implications for Radiation Balance, Microclimate, and Gas Exchange. Ecosystems 2004, 7, 440-453. [CrossRef]

24. Wulder, M.A.; Bater, C.W.; Coops, N.C.; Hilker, T.; White, J.C. The role of LiDAR in sustainable forest management. For. Chron. 2008, 84, 807-826. [CrossRef]

25. Bolton, D.K.; Coops, N.C.; Wulder, M.A. Measuring Forest structure along productivity gradients in the Canadian boreal with small-footprint Lidar. Environ. Monit. Assess. 2013, 185, 6617-6634. [CrossRef]

26. Monsi, M.; Uchijima, Z.; Oikawa, T. Structure of Foliage Canopies and Photosynthesis. Annu. Rev. Ecol. Syst. 1973, 4, 301-327. [CrossRef]

27. Rasmussen, J.; Ntakos, G.; Nielsen, J.; Svensgaard, J.; Poulsen, R.N.; Christensen, S. Are vegetation indices derived from consumer-grade cameras mounted on UAVs sufficiently reliable for assessing experimental plots? Eur. J. Agron. 2016, 74, 75-92. [CrossRef]

28. Bendig, J.; Yu, K.; Aasen, H.; Bolten, A.; Bennertz, S.; Broscheit, J.; Gnyp, M.L.; Bareth, G. Combining UAV-based plant height from crop surface models, visible, and near infrared vegetation indices for biomass monitoring in barley. Int. J. Appl. Earth Obs. 2015, 39, 79-87. [CrossRef]

29. Casadesús, J.; Kaya, Y.; Bort, J.; Nachit, M.M.; Araus, J.L.; Amor, S.; Ferrazzano, G.; Maalouf, F.; Maccaferri, M.; Martos, V.; et al. Using vegetation indices derived from conventional digital cameras as selection criteria for wheat breeding in water-limited environments. Ann. Appl. Biol. 2007, 150, 227-236. [CrossRef] 
30. Xue, J.; Su, B. Significant Remote Sensing Vegetation Indices: A Review of Developments and Applications. J. Sens. 2017, 2017, 1353691. [CrossRef]

31. Hernández-Clemente, R.; Navarro-Cerrillo, R.M.; Zarco-Tejada, P.J. Carotenoid content estimation in a heterogeneous conifer forest using narrow-band indices and PROSPECT + DART simulations. Remote Sens. Environ. 2012, 127, 298-315. [CrossRef]

32. Burkart, A.; Hecht, V.L.; Kraska, T.; Rascher, U. Phenological analysis of unmanned aerial vehicle based time series of barley imagery with high temporal resolution. Precis. Agric. 2018, 19, 134-146. [CrossRef]

33. Santini, F.; Kefauver, S.C.; Resco De Dios, V.; Araus, J.L.; Voltas, J. Using unmanned aerial vehicle-based multispectral, RGB and thermal imagery for phenotyping of forest genetic trials: A case study in Pinus halepensis. Ann. Appl. Biol. 2019, 174, 262-276. [CrossRef]

34. Jing, L.; Hu, B.; Noland, T.; Li, J. An individual tree crown delineation method based on multi-scale segmentation of imagery. ISPRS J. Photogramm. 2012, 70, 88-98. [CrossRef]

35. Hyyppa, J.; Kelle, O.; Lehikoinen, M.; Inkinen, M. A segmentation-based method to retrieve stem volume estimates from 3-D tree height models produced by laser scanners. IEEE Trans. Geosci. Remote Sens. 2001, 39, 969-975. [CrossRef]

36. Lu, X.; Guo, Q.; Li, W.; Flanagan, J. A bottom-up approach to segment individual deciduous trees using leaf-off lidar point cloud data. ISPRS J. Photogramm. 2014, 94, 1-12. [CrossRef]

37. Li, W.; Guo, Q.; Jakubowski, M.K.; Kelly, M. A New Method for Segmenting Individual Trees from the Lidar Point Cloud. Photogramm. Eng. Remote Sens. 2012, 78, 75-84. [CrossRef]

38. Li, P.; Shen, X.; Dai, J.; Cao, L. Comparisons and Accuracy Assessments of LiDAR-Based Tree Segmentation Approaches in Planted Forests. Sci. Silvae Sin. 2018, 54, 127-136. [CrossRef]

39. Li, Y.; He, H.; Huang, X. Analysis on climate change in Nanning city in recent 50 years. J. Guangxi Univ. Nat. Sci. Ed. 2007, 2007, 159-162. [CrossRef]

40. Bengio, Y. Grandvalet. No Unbiased Estimator of the Variance of K-Fold Cross-Validation. J. Mach. Learn. Res. 2003, 5, $1089-1105$.

41. Zhao, X.; Guo, Q.; Su, Y.; Xue, B. Improved progressive TIN densification filtering algorithm for airborne LiDAR data in forested areas. ISPRS J. Photogramm. 2016, 117, 79-91. [CrossRef]

42. Næsset, E.; Økland, T. Estimating tree height and tree crown properties using airborne scanning laser in a boreal nature reserve. Remote Sens. Environ. 2002, 79, 105-115. [CrossRef]

43. Woods, M.; Lim, K.; Treitz, P. Predicting Forest stand variables from LiDAR data in the Great Lakes-St. Lawrence Forest of Ontario. For. Chron. 2008, 84, 827-839. [CrossRef]

44. Solberg, S.; Næsset, E.; Hanssen, K.H.; Christiansen, E. Mapping defoliation during a severe insect attack on Scots pine using airborne laser scanning. Remote Sens. Environ. 2006, 102, 364-376. [CrossRef]

45. Coops, N.C.; Hilker, T.; Wulder, M.A.; St-Onge, B.; Newnham, G.; Siggins, A.; Trofymow, J.A.T. Estimating canopy structure of Douglas-fir Forest stands from discrete-return LiDAR. Trees 2007, 21, 295-310. [CrossRef]

46. Lefsky, M.A.; Cohen, W.B.; Acker, S.A.; Parker, G.G.; Spies, T.A.; Harding, D. Lidar Remote Sensing of the Canopy Structure and Biophysical Properties of Douglas-Fir Western Hemlock Forests. Remote Sens. Environ. 1999, 70, 339-361. [CrossRef]

47. Fraser, R.; van der Sluijs, J.; Hall, R. Calibrating Satellite-Based Indices of Burn Severity from UAV-Derived Metrics of a Burned Boreal Forest in NWT, Canada. Remote Sens. 2017, 9, 279. [CrossRef]

48. Verrelst, J.; Schaepman, M.E.; Koetz, B.; Kneubühler, M. Angular sensitivity analysis of vegetation indices derived from CHRIS/PROBA data. Remote Sens. Environ. 2008, 112, 2341-2353. [CrossRef]

49. Meyer, G.E.; Neto, J.C. Verification of color vegetation indices for automated crop imaging applications. Comput. Electron. Agric. 2008, 63, 282-293. [CrossRef]

50. Gitelson, A.A.; Kaufman, Y.J.; Stark, R.; Rundquist, D. Novel algorithms for remote estimation of vegetation fraction. Remote Sens. Environ. 2002, 80, 76-87. [CrossRef]

51. Wang, X.; Wang, M.; Wang, S.; Wu, Y. Extraction of vegetation information from visible unmanned aerial vehicle images. Trans. Chin. Soc. Agric. Eng. 2015, 31, 152-157. [CrossRef]

52. Neto, J.C. A Combined Statistical-Soft Computing Approach for Classification and Mapping Weed Species in Minimum-Tillage Systems; University of Nebraska: Lincoln, NE, USA, 2006.

53. Kataoka, T.; Kaneko, T.; Okamoto, H.; Hata, S. Crop growth estimation system using machine vision. In Proceedings of the 2003 IEEE/ASME International Conference on Advanced Intelligent Mechatronics, Kobe, Japan, 20-24 July 2003; pp. b1079-b1083. [CrossRef]

54. Najman, L.; Couprie, M.; Bertrand, G. Watersheds, mosaics, and the emergence paradigm. Discrete Appl. Math. 2005, 147, 301-324. [CrossRef]

55. Chen, Q.; Baldocchi, D.; Gong, P.; Kelly, M. Isolating Individual Trees in a Savanna Woodland Using Small Footprint Lidar Data. Photogramm. Eng. Remote Sens. 2006, 72, 923-932. [CrossRef]

56. Goutte, C.; Gaussier, E. A Probabilistic Interpretation of Precision, Recall and F-Score, with Implication for Evaluation. Int. J. Radiat. Biol. Relat. Stud. Phys. Chem. Med. 2005, 3408, 345-359. [CrossRef]

57. Sokolova, M.; Japkowicz, N.; Szpakowicz, S. Beyond Accuracy, F-Score and ROC: A Family of Discriminant Measures for Performance Evaluation. In Australasian Joint Conference on Artificial Intelligence; Springer: Berlin/Heidelberg, Germany, 2006; pp. 1015-1021. [CrossRef]

58. Wang, M. The Forest Genetics and Breeding; Forestry Publishing House: Beijing, China, 2001; pp. $203-214$. 
59. Lai, M. Genotypic Evaluation and Early Selection of Larix Clones; Chinese Academy of Forestry: Beijing, China, $2014 ;$ p. 123.

60. Wang, J.; Mo, Y.; Shen, L.; Fu, C.; Li, C.; Wei, G. Genetic Variation Analysis and Selection of 23 Eucalyptus Clonesin in Southern Guangxi. Southwest China J. Agric. Sci. 2019, 32, 2174-2179. [CrossRef]

61. Xie, Y.; Mo, X.; Peng, S.; Deng, H.; Liu, L. Genetic variation analysis and early comprehensive selection of 21 Eucalyptus clones in western Guangdong Province, China. Nanjing For. Univ. Nat. Sci. Ed. 2018, 42, 73-80. [CrossRef]

62. Xu, J. Application of Repeatability in Tree Breeding. J. Beijing For. Univ. 1988, 1988, 97-102. [CrossRef]

63. Wu, Y.; Mao, C. Simple Introduction to Heritability, Repeatability and Genetic Gain in Percent in Tree Breeding. Trop. Agric. Sci. Technol. 2012, 35, 47-50. [CrossRef]

64. Sotelo Montes, C.; Hernández, R.E.; Beaulieu, J.; Weber, J.C. Genetic variation in wood color and its correlations with tree growth and wood density of Calycophyllum spruceanum at an early age in the Peruvian Amazon. New For. 2007, 35, 57-73. [CrossRef]

65. Li, G.Y.; Xu, J.M.; Lu, Z.H.; Du, Z.H.; Han, C.; Wu, S.J.; Wang, W. Growing and form-quality study on the clones of Eucalyptus in southern Fujian. J. Cent. South Univ. For. Technol. 2012, 32, 21-25. [CrossRef]

66. Xu, J.; Lu, Z.; Li, G.; Bai, J. Study on Integrated Selection of Provenances-families of Eucalytus tereticornis. For. Res. 2003, 16, 1-7. [CrossRef]

67. Chen, X.; Shen, X. Forest Tree Breeding; Higher Education Press: Beijing, China, 2005; p. 145.

68. Vauhkonen, J.; Ene, L.; Gupta, S.; Heinzel, J.; Holmgren, J.; Pitkanen, J.; Solberg, S.; Wang, Y.; Weinacker, H.; Hauglin, K.M.; et al. Comparative testing of single-tree detection algorithms under different types of forest. Forestry 2012, 85, 27-40. [CrossRef]

69. Yang, Q.; Su, Y.; Jin, S.; Kelly, M.; Hu, T.; Ma, Q.; Li, Y.; Song, S.; Zhang, J.; Xu, G.; et al. The Influence of Vegetation Characteristics on Individual Tree Segmentation Methods with Airborne LiDAR Data. Remote Sens. 2019, 11, 2880. [CrossRef]

70. Guo, Y.; Liu, Q.; Liu, G.; Huang, C. Individual tree crown extraction of high resolution image based on marker-controlled watershed segmentation method. J. Geo. Inf. Sci. 2016, 18, 1259-1266. [CrossRef]

71. Bai, S. Research on Single Tree Segmentation and DBH Parameter Extraction Algorithm Based on Point Cloud Data; Beijing University of Civil Engineering and Architecture: Beijing, China, 2020; p. 67. [CrossRef]

72. Wu, X.; Shen, X.; Cao, L.; Wang, G.; Cao, F. Assessment of Individual Tree Detection and Canopy Cover Estimation using Unmanned Aerial Vehicle based Light Detection and Ranging (UAV-LiDAR) Data in Planted Forests. Remote Sens. 2019, 11, 908. [CrossRef]

73. Walter, J.D.C.; Edwards, J.; McDonald, G.; Kuchel, H. Estimating Biomass and Canopy Height with LiDAR for Field Crop Breeding. Front. Plant Sci. 2019, 10, 1145. [CrossRef]

74. White, J.C.; Coops, N.C.; Wulder, M.A.; Vastaranta, M.; Hilker, T.; Tompalski, P. Remote Sensing Technologies for Enhancing Forest Inventories: A Review. Can. J. Remote Sens. 2016, 42, 619-641. [CrossRef]

75. Camarretta, N.; Harrison, P.A.; Lucieer, A.; Potts, B.M.; Davidson, N.; Hunt, M. From Drones to Phenotype: Using UAV-LiDAR to Detect Species and Provenance Variation in Tree Productivity and Structure. Remote Sens. 2020, 12, 3184. [CrossRef]

76. Du Toit, F.; Coops, N.C.; Tompalski, P.; Goodbody, T.R.H.; El-Kassaby, Y.A.; Stoehr, M.; Turner, D.; Lucieer, A. Characterizing variations in growth characteristics between Douglas-fir with different genetic gain levels using airborne laser scanning. Trees 2020, 34, 649-664. [CrossRef]

77. Liu, M.; Yin, S.; Si, D.; Shao, L.; Li, Y.; Zheng, M.; Wang, F.; Li, S.; Liu, G.; Zhao, X. Variation and genetic stability analyses of transgenic TaLEA poplar clones from four different sites in China. Euphytica 2015, 206, 331-342. [CrossRef]

78. Jiang, L.; Pei, X.; Hu, Y.; Chiang, V.L.; Zhao, X. Effects of environment and genotype on growth traits in poplar clones in Northeast China. Euphytica 2021, 217, 1-14. [CrossRef]

79. Meena, B.L.; Das, S.P.; Meena, S.K.; Kumari, R.; Devi, A.G.; Devi, H.L. Assessment of GCV, PCV, Heritability and Genetic Advance for Yield and its Components in Field Pea (Pisum sativum L.). Int. J. Curr. Microbiol. App. Sci. 2017, 6, 1025-1033. [CrossRef]

80. Liziniewicz, M.; Ene, L.T.; Malm, J.; Lindberg, J.; Helmersson, A.; Karlsson, B. Estimation of Genetic Parameters and Selection of Superior Genotypes in a 12-Year-Old Clonal Norway Spruce Field Trial after Phenotypic Assessment Using a UAV. Forest 2020, 11, 992. [CrossRef]

81. Cao, J.; Luo, J.; Lu, W. Cluster Analysis on Growth Trait of 6-year-old Eucalypt Clone Stands. Eucalypt Sci. Technol. 2012, 29, 37-40. [CrossRef]

82. Chen, J.; Li, C.; Xiang, D.; Guo, D.; Ren, S.; Deng, Y.; Xu, J. Heterosis test for Eucalyptus hybrid families including Eucalyptus urophylla $\times$ Eucalyptus grandis. J. South. Agric. 2017, 48, 1858-1862. [CrossRef]

83. Xu, Z.; Shen, X.; Cao, L.; Coops, N.C.; Goodbody, T.R.H.; Zhong, T.; Zhao, W.; Sun, Q.; Ba, S.; Zhang, Z.; et al. Tree species classification using UAS-based digital aerial photogrammetry point clouds and multispectral imageries in subtropical natural forests. Int. J. Appl. Earth Obs. 2020, 92, 102173. [CrossRef]

84. Jin, S.; Su, Y.; Gao, S.; Wu, F.; Hu, T.; Liu, J.; Li, W.; Wang, D.; Chen, S.; Jiang, Y.; et al. Deep Learning: Individual Maize Segmentation from Terrestrial Lidar Data Using Faster R-CNN and Regional Growth Algorithms. Front. Plant Sci. 2018, 9, 866. [CrossRef]

85. Pont, D.; Dungey, H.S.; Suontama, M.; Stovold, G.T. Spatial Models with Inter-Tree Competition from Airborne Laser Scanning Improve Estimates of Genetic Variance. Front. Plant Sci. 2021, 11, 596315. [CrossRef] [PubMed]

86. Perich, G.; Hund, A.; Anderegg, J.; Roth, L.; Boer, M.P.; Walter, A.; Liebisch, F.; Aasen, H. Assessment of Multi-Image Unmanned Aerial Vehicle Based High-Throughput Field Phenotyping of Canopy Temperature. Front. Plant Sci. 2020, 11, 150. [CrossRef] [PubMed] 